\title{
Implementing nickel phytomining in a serpentine quarry in NW Spain
}

\author{
Andrea Cerdeira-Pérez ${ }^{\mathrm{a}, *}$, Carmela Monterroso ${ }^{\mathrm{b}}$, Beatriz Rodríguez-Garrido ${ }^{\mathrm{a}}$, Gaylord Machinet ${ }^{\mathrm{c}}$, \\ Guillaume Echevarria ${ }^{\mathrm{d}}$, Ángeles Prieto-Fernández ${ }^{\mathrm{a}}$, Petra Susan Kidd ${ }^{\mathrm{a}}$ \\ ${ }^{\mathrm{a}}$ Instituto de Investigaciones Agrobiológicas de Galicia (IIAG), Consejo Superior de Investigaciones Científicas (CSIC), 15705 Santiago de Compostela, Spain \\ b Departamento de Edafología y Química Agrícola, Universidad de Santiago de Compostela, 15782 Santiago de Compostela, Spain \\ ${ }^{\mathrm{c}}$ Microhumus, Université de Lorraine, Laboratoire Sols et Environnement, UMR 1120, Vandoeuvre-lès-Nancy F-54518, France \\ ${ }^{\mathrm{d}}$ Université de Lorraine, INRA, Laboratoire Sols et Environnement, 54000 Nancy, France
}

\section{A R T I C L E I N F O}

\section{Keywords:}

Alyssum s.l.

Agromining

Hyperaccumulator

Organic amendments

Ultramafic

\begin{abstract}
A B S T R A C T
In Galicia (NW Spain), ultramafic outcrops represent approximately 5\% of the land surface and several mining and quarrying activities take place in these areas. Resulting mine-soils present physical, chemical and biological properties which limit plant growth and soil functioning. Nickel phytomining, an eco-friendly strategy for metal recovery, could potentially be applied to these areas. A one-year field experiment was carried out in a serpentine quarry to evaluate the performance of four Ni hyperaccumulating plant species, comparing the Mediterranean spp. Bornmuellera emarginata and Odontarrhena muralis with the native populations of Noccaea caerulescens and Odontarrhena serpyllifolia. Field plots were established and amended with inorganic NPK fertilisers or composted sewage sludge. Three replicate plots $\left(4 \mathrm{~m}^{2}\right)$ were planted for each plant species and fertilisation regime. Amending with compost reduced $\mathrm{pH}$ from 7.8 to 6.6 , and increased soil cation exchange capacity (CEC), nutrient concentrations and $\mathrm{Ni}$ availability. Moreover, compost-amended mine-soil presented higher microbial density and activity, parameters which were further stimulated by plant growth. Plant biomass production of all plant species was significantly higher in compost-amended soils than that after NPK fertilisation, being most pronounced for $O$. muralis and $B$. emarginata. Despite the reduction in shoot Ni concentrations observed in plants (except $O$. muralis) grown in compost-amended plots, the increased biomass production led to significantly higher Ni yields (in $\mathrm{kg} \mathrm{ha}^{-1}$ ) in B. emarginata (2.9), N. caerulescens (1.9) and O. muralis (2.3). All plant species were able to establish and grow in the mine-soil (with the Mediterranean species showing a higher capacity for adaptation) and to generate moderate Ni yields. Nonetheless, the results highlight the need for further optimisation in order to enhance the Ni phytoextraction efficiency. Finally, the improvement in soil quality after compost amendment and plant growth support the idea that phytomining systems can be effective approaches for the rehabilitation of soils affected by quarrying operations after mine closure.
\end{abstract}

\section{Introduction}

Mining and quarrying activities exist since pre-historic times but the demand for raw materials has experienced an unprecedented growth since the early 20th century alongside an increasing global population and the development of new and existing technologies. The European Innovation Partnership (EIP) classified Ni as a raw material with high economic importance (EC, 2017). Traditional pyro- and hydro-metallurgical processes for nickel extraction require high energy and chemical inputs, and are usually performed on sulphide (and laterite) ores with elevated concentration(s) of the target metal(s). However, these ores are not widely distributed and for many elements, such as nickel, available reserves are gradually diminishing (Dalvi et al., 2004;
Sheoran et al., 2009). Moreover, mining and quarrying operations have significant negative impacts on the environment, leading to changes in the landscape topography and generating large amounts of waste (during extraction and beneficiation processes) with associated release of potentially toxic elements into their surroundings. Mine tailings, heaps or dumps can also indirectly result in air and water pollution (Lago-Vila et al., 2017).

As a result, the European Commission (EC), within the framework of the Raw Materials Initiative, encourages the development of new means of metal extraction and reuse, and supports the shift towards a circular economy to ensure the secure supply of raw materials while minimising waste production (Dodson et al., 2012). Amongst the identified possible actions, the EC highlights the recovery of valuable metals from

\footnotetext{
* Corresponding author.

E-mail address: acerdeira@iiag.csic.es (A. Cerdeira-Pérez).
} 
secondary sources, including wastes generated by the mining industry (EC, 2018). Phytomining is an environmentally-friendly green technology for obtaining industrially relevant trace elements from subeconomic ore bodies (such as low-grade natural metal-enriched soils), degraded or contaminated land, or waste streams, which meets with the goals of the EC in terms of elemental sustainability (Dodson et al., 2012; Nkrumah et al., 2016).

Nickel phytomining cultivates hyperaccumulator plant species ("metal crops") which can accumulate high amounts of this metal in their aboveground tissues: the harvested Ni-rich plant biomass is incinerated to obtain an ash or "bio-ore" that can be processed to recover metallic Ni or Ni-products, such as ferronickel, Ni salts, or Ni catalysts (Barbaroux et al., 2012; Simonnot et al., 2018). Serpentine soils, formed during the alteration of ultramafic rocks, are of great interest for $\mathrm{Ni}$ phytomining since they represent important Ni reservoirs of the Earth's surface (Proctor and Woodell, 1975). Moreover, due to their particular geochemical properties and associated flora they constitute hotspots of plant biodiversity (Echevarria, 2018), and over 90\% of known Ni hyperaccumulating plant species are endemic to these soils (Pollard et al., 2014; Reeves et al., 2018). Geographically, Ni hyperaccumulators belong to two groups: (1) the Mediterranean region and (2) tropical and subtropical areas (Reeves et al., 2018). The first group is mainly represented by the Brassicaceae family and most studies in this field have evaluated the Ni phytoextraction potential of the Mediterranean hyperaccumulators belonging to the Odontarrhena genus (syn. Alyssum), mainly Odontarrhena muralis and O. corsica (Bani et al., 2015a; Li et al., 2003). Other Brassicaceae recognised for their phytomining potential include Bornmuellera emarginata (syn. Leptoplax emarginata) (Rešetnik et al., 2013) and B. tymphaea (Chardot et al., 2005). Nickel phytomining field trials have been carried out in agricultural soils developed over ultramafic rocks in Pöjske (Albania), Galicia (NW Spain) and Oregon (USA), with promising results (Bani et al., 2015a, 2007; Li et al., 2003; Pardo et al., 2018). In contrast, field-scale evaluations in mine-affected areas are rare, with recent initiatives being restricted to tropical regions, such as New Caledonia (Losfeld et al., 2015), Sabah (Malaysia) and the Philippines (van der Ent et al., 2013). These studies aim to produce metal-enriched plant biomass for $\mathrm{Ni}$ recovery using tropical hyperaccumulating species, while at the same time contributing towards the rehabilitation of mine-affected areas.

In Galicia (NW Spain), serpentine outcrops represent approximately $5 \%$ of the land surface (about $1470 \mathrm{~km}^{2}$ ), and several mining activities are dedicated to the extraction of rocks for industrial or ornamental use, generating large amounts of sterile material which is accumulated in spoil heaps and tailings (Lago-Vila et al., 2017; Rodríguez-Seijo et al., 2014). Implementing phytomining options in these serpentine quarries could provide an additional metal source to primary ores and at the same time reduce hazardous waste volumes and assist site restoration. However, the lack of soil structure, low water holding capacity, limited organic matter content and nutrient deficiency, which are typical characteristics of mine-soils, make these environments unfavourable for plant growth and development, even in the case of metal-tolerant hyperaccumulators (Ernst, 2005). Elevated concentrations of potentially phytotoxic metals (in addition to $\mathrm{Ni}$ ), such as $\mathrm{Cr}$ or $\mathrm{Co}$, as well as an alkaline $\mathrm{pH}$, can further exasperate the plant-growth limiting factors of serpentine mine-soils. Since both biomass production and a high concentration of the desired element in the harvestable plant parts are key factors for the success of phytomining (Reeves et al., 2018), improving soil conditions will play a central role in the development of these strategies in mine-affected areas. The use of mature (stabilised) organic amendments resulted in a significant stimulation in plant growth and $\mathrm{Ni}$ phytoextraction capacity of $\mathrm{Ni}$ hyperaccumulators of the Odontarrhena and Noccaea genera in pot trials using both natural ultramafic soils (Álvarez-López et al., 2016b) and serpentine quarry tailings (Ghasemi et al., 2018a). However, there is a need to evaluate the potential benefits of these amendments at a field-scale.

In this study the feasibility of Ni phytomining in serpentine mine spoils was assessed using four $\mathrm{Ni}$ hyperaccumulating species (Bornmuellera emarginata, Noccaea caerulescens, Odontarrhena muralis and $O$. serpyllifolia). In addition, the effects of incorporating composted sewage sludge as soil amendment on plant growth, biomass production and Ni bioaccumulation of the four hyperaccumulators was compared with inorganic NPK fertilisation.

\section{Material and methods}

\subsection{Study site}

The field experiment was carried out in a serpentine quarry in

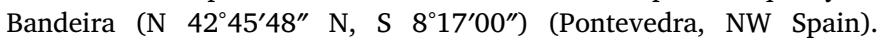
Bandeira is located in the Melide-Serra do Careón geological complex, which represents one of the three main serpentine outcrops of the Iberian Peninsula (Macías et al., 2009). It is characterised climatically by a high precipitation (annual mean $1375 \mathrm{~mm}$ ) and mild temperatures (annual mean $12.6{ }^{\circ} \mathrm{C}$ ). The active opencast mine is embedded in a substrate of amphibolites and serpentines, covering an area of 40 ha and is dedicated to the extraction of serpentinised peridotite for the production of gravel for construction and ballast for railway tracks. The generated sterile material is accumulated in spoil heaps and these cover an area of around $3.4 \mathrm{~km}^{2}$ (Fig. 1). The soil derived from the spoil material - classified as Spolic Technosol (IUSS Working Group WRB, 2014) - is shallow and gravelly, with a poor structure, low water retention capacity and is mostly bare of vegetation, with Cortaderia selloana as the only successful colonising plant species.

The physico-chemical mine-soil characteristics given in Table 1 are in accordance with the geological complex of the area. The mine-soil is characterised by a basic $\mathrm{pH}$ (7.8) and poor fertility, which is reflected in the low total $\mathrm{C}$ and $\mathrm{N}$ content and nutrient concentrations (available $\mathrm{P}$ and $\mathrm{K}$ ). Furthermore, the mine-soils are characterised by elevated concentrations of metals such as $\mathrm{Ni}\left(2302 \mathrm{mg} \mathrm{kg}^{-1}\right), \mathrm{Cr}\left(1379 \mathrm{mg} \mathrm{kg}^{-1}\right)$ and $\mathrm{Co}\left(84 \mathrm{mg} \mathrm{kg}^{-1}\right)$. On the other hand, although the pseudo-total $\mathrm{Mg}$ concentration is much higher than that observed for $\mathrm{Ca}$ - which is typical of ultramafic soils, Ca dominates the cation exchange complex, thus maintaining a balanced $\mathrm{Ca}$ to $\mathrm{Mg}$ relation $(\mathrm{Ca} / \mathrm{Mg}=1.0$; (Table 1 ).

\subsection{Plant species and experimental design}

Four Ni hyperaccumulating plant species were selected for this study: Odontarrhena serpyllifolia (Desf.) Jord \& Fourr. (syn. Alyssum serpyllifolium subsp. lusitanicum T.R. Dudley \& P.C. Silva) and Noccaea caerulescens (J. Presl \& C. Presl) F.K. Mey, which are both found growing in the serpentine soils of the Iberian Peninsula, and Odontarrhena muralis (Waldst. \& Kit). Endl. (syn. Alyssum murale) and Bornmuellera emarginata (Boiss.) Resetnik (syn. Leptoplax emarginata O.E. Schulz), which are native to Mediterranean serpentine soils. Seeds of $O$. muralis and B. emarginata were collected from the region of Trigona (Greece), O. serpyllifolia from Melide (NW Spain) and Noccaea caerulescens from Bandeira (NW Spain). Seeds were germinated in plastic trays (each with 81 plugs of $30 \mathrm{ml}$ volume) filled with commercial potting substrate (Terrahumus) in a growth chamber under controlled conditions (temperature $22-25^{\circ} \mathrm{C}$, PPFD of $190 \mu \mathrm{mol} \mathrm{m}^{-2} \mathrm{~s}^{-1}, 16 / 8 \mathrm{~h}$ light/dark cycle) for two months before planting in the field.

In September 2016 an area of the spoils was cleared of vegetation, broken-up and tilled using a front loader tractor (the first $30-40 \mathrm{~cm}$ of surface soil). The experimental area was fenced-off and divided into two blocks, with a surface area of $105 \mathrm{~m}^{2}$ each. One block was fertilised with inorganic NPK in the form of $\mathrm{NH}_{4} \mathrm{NO}_{3}\left(480 \mathrm{~kg} \mathrm{ha}^{-1}\right)$ and $\mathrm{KH}_{2} \mathrm{PO}_{4}$ $\left(400 \mathrm{~kg} \mathrm{ha}^{-1}\right.$ ) and the other block was amended with composted sewage sludge at an addition rate of $210 \mathrm{tha}^{-1}$ (equivalent to $5 \% \mathrm{w} /$ w). Addition rates were based on previous pot experiments (unpublished results). The compost was elaborated from sewage sludge and wood chippings by a local company (Tratamientos Ecológicos del 


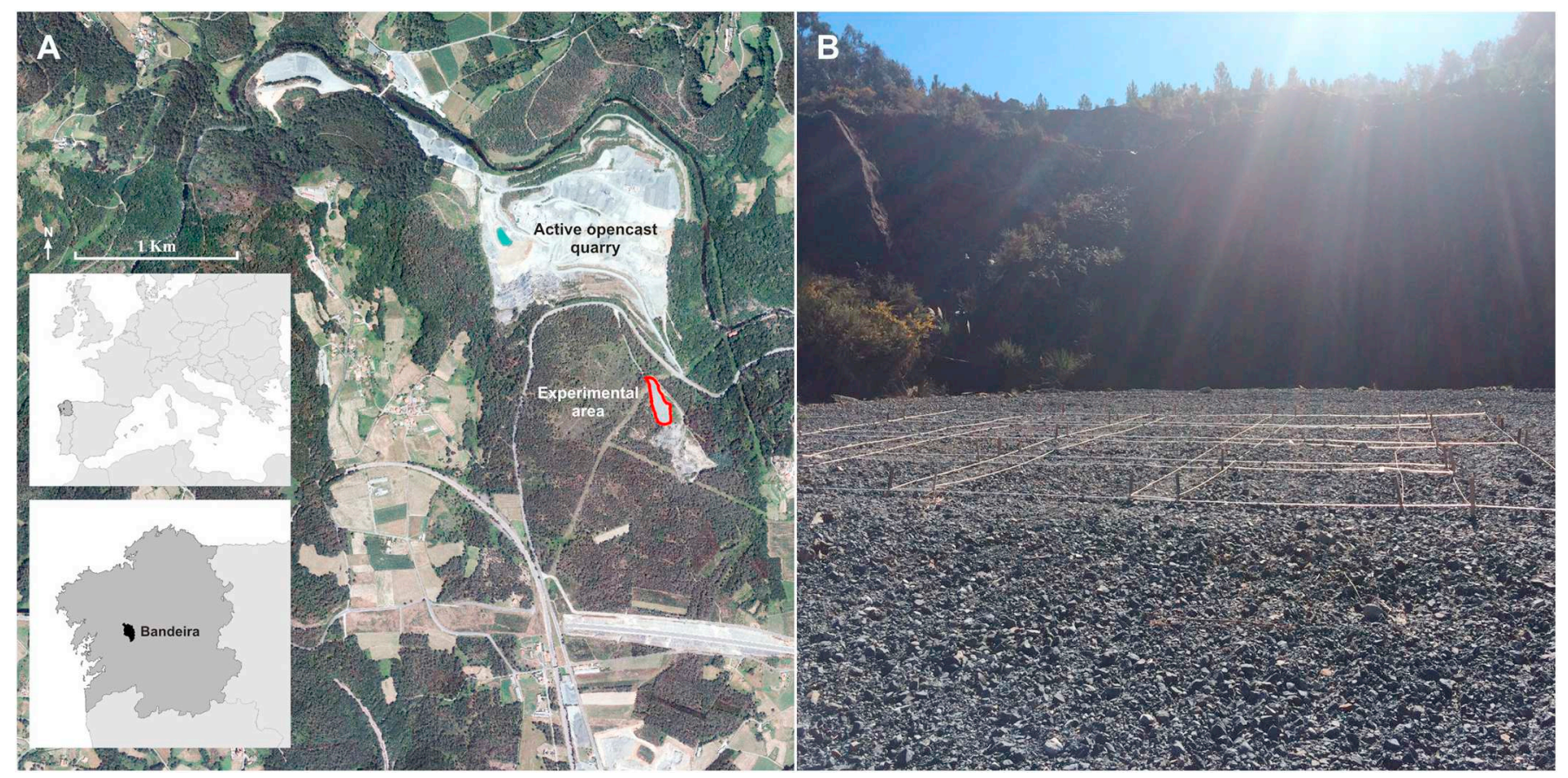

Fig. 1. A) Location of the serpentine quarry and, B) image of the experimental area before planting.

Table 1

Physico-chemical properties (mean \pm SE) of the mine soil, the mine soil two months after the addition of composted sewage sludge (Mine soil + CSS) and the compost (CSS). Hyphens represent non-measured parameters.

\begin{tabular}{|c|c|c|c|}
\hline & Mine soil & Mine soil + CSS & CSS \\
\hline $\mathrm{pH} \mathrm{H}_{2} \mathrm{O}$ & $7.8 \pm 0.0$ & $6.6 \pm 0.0$ & $6.0 \pm 0.4$ \\
\hline $\mathrm{pH} \mathrm{KCl}$ & $7.3 \pm 0.0$ & $6.1 \pm 0.0$ & $6.0 \pm 0.0$ \\
\hline $\mathrm{P}$ Olsen $\left(\mu \mathrm{kg}^{-1}\right)$ & $2.1 \pm 0.4$ & $240.8 \pm 8.3$ & $1704.0 \pm 103.4$ \\
\hline $\operatorname{CEC}\left(\mathrm{cmol}_{\mathrm{c}} \mathrm{kg}^{-1}\right)$ & $3.5 \pm 0.3$ & $19.2 \pm 1.7$ & $42.0 \pm 4.3$ \\
\hline Exchangeable $\mathrm{Ca}\left(\mathrm{cmol}_{\mathrm{c}} \mathrm{kg}^{-1}\right)$ & $1.8 \pm 0.2$ & $6.7 \pm 0.4$ & $11.7 \pm 0.5$ \\
\hline Exchangeable $\mathrm{Mg}\left(\mathrm{cmol}_{\mathrm{c}} \mathrm{kg}^{-1}\right)$ & $1.7 \pm 0.1$ & $9.6 \pm 0.9$ & $17.7 \pm 0.8$ \\
\hline Exchangeable $\mathrm{K}\left(\mathrm{cmol}_{\mathrm{c}} \mathrm{kg}^{-1}\right)$ & $0.1 \pm 0.0$ & $2.8 \pm 0.4$ & $12.6 \pm 0.4$ \\
\hline $\mathrm{Ca} / \mathrm{Mg}$ & $1.0 \pm 0.1$ & $0.7 \pm 0.0$ & $0.7 \pm 0.1$ \\
\hline$\% \mathrm{C}$ & $0.68 \pm 0.01$ & $6.03 \pm 0.40$ & $16.10 \pm 0.20$ \\
\hline$\% \mathrm{~N}$ & $0.04 \pm 0.01$ & $0.59 \pm 0.04$ & $1.40 \pm 0.01$ \\
\hline $\mathrm{C} / \mathrm{N}$ & $13.7 \pm 1.1$ & $10.4 \pm 0.0$ & $12.0 \pm 0.1$ \\
\hline Hydrosoluble C $\left(\mathrm{mg} \mathrm{l}^{-1}\right)$ & - & - & $49.8 \pm 7.1$ \\
\hline Hydrosoluble $\mathrm{N}\left(\mathrm{mg} \mathrm{l}^{-1}\right)$ & - & - & $52.4 \pm 4.1$ \\
\hline \multicolumn{4}{|c|}{$\begin{array}{l}\text { Pseudo-total element concentrations } \\
\mathrm{g} \mathrm{kg}^{-1}\end{array}$} \\
\hline $\mathrm{P}$ & $0.1 \pm 0.0$ & $0.4 \pm 0.0$ & $16.5 \pm 0.3$ \\
\hline $\mathrm{K}$ & $0.2 \pm 0.0$ & $4.3 \pm 0.0$ & $8.9 \pm 0.1$ \\
\hline $\mathrm{Al}$ & $8.0 \pm 0.0$ & $26.4 \pm 0.0$ & $31.3 \pm 0.7$ \\
\hline $\mathrm{Ca}$ & $2.6 \pm 0.0$ & $5.2 \pm 0.0$ & $7.9 \pm 0.1$ \\
\hline $\mathrm{Mg}$ & $216.8 \pm 0.2$ & $120.7 \pm 0.1$ & $10.4 \pm 0.1$ \\
\hline \multicolumn{4}{|l|}{$\mathrm{mg} \mathrm{kg}^{-1}$} \\
\hline $\mathrm{Cr}$ & $1178.9 \pm 12.1$ & $719.3 \pm 51.2$ & $41.0 \pm 1.4$ \\
\hline $\mathrm{Cu}$ & $11.3 \pm 12.1$ & $63.2 \pm 3.4$ & $168.4 \pm 2.8$ \\
\hline Mn & $698.1 \pm 6.0$ & $606.7 \pm 7.4$ & $459.3 \pm 1.4$ \\
\hline $\mathrm{Ni}$ & $1694.1 \pm 14.4$ & $977.2 \pm 38.7$ & $32.7 \pm 0.1$ \\
\hline $\mathrm{Zn}$ & $20.7 \pm 0.1$ & $128.6 \pm 5.9$ & $311.5 \pm 6.7$ \\
\hline
\end{tabular}

Noroeste, TEN s.l) and its principal physico-chemical properties are given in Table 1 . The compost was quite fine $(<2 \mathrm{~mm}$ fraction representing $51 \%$ of mass), indicating a high accessibility of organic matter. The coarse fraction $(>2 \mathrm{~mm}$ ) contributes to soil aeration. Assessments using transmission electronic microscopy (TEM) showed that the $<2 \mathrm{~mm}$ fraction was mainly composed by highly transformed organic matter (humified plant cell walls and bacterial residues) reflecting a high maturity (stable carbon). The coarse fraction ( $>2 \mathrm{~mm}$ ) was composed by ligneous residues, which was incompletely transformed and constitutes a source of labile carbon for soil microorganisms (unpublished results). The compost presented a slightly acidic $\mathrm{pH}, \mathrm{C} / \mathrm{N}$ ratio of 12 , high $\mathrm{CEC}$, and low to moderate concentration of the trace metals $\mathrm{Cu}, \mathrm{Mn}$, and $\mathrm{Zn}$ (Table 1).

Both blocks were divided into 16 plots of $4 \mathrm{~m} \times 4 \mathrm{~m}$, with a $1 \mathrm{~m}$ spacing between each of them. Three random replicate plots were established for each plant species in each block. Odontarrhena serpyllifolia, $O$. muralis and B. emarginata were planted at a density of 4 plants $\mathrm{m}^{-2}$, and in the case of $N$. caerulescens planting density was 90 plants $\mathrm{m}^{-2}$. 
Three non-planted plots were established in both blocks to evaluate the effects of plant growth on soil physico- and bio-chemical properties. Plants were harvested after 10 months of growth in July 2017, and during the growth period weeds were manually removed.

\subsection{Plant analysis}

Plant biomass production, nutritional status and metal content were determined for each plant species and plot at harvest. Plants were divided into shoots and roots, washed with pressurised tap water followed by deionised water, and oven-dried at $40{ }^{\circ} \mathrm{C}$ to determine the dry weight (DW). Dried root and shoot material was ground and approximately $0.1 \mathrm{~g}$ of plant material was digested in a $2: 1$ concentrated $\mathrm{HNO}_{3}: \mathrm{HCl}$ mixture on a hot plate at $130^{\circ} \mathrm{C}$. The concentration of $\mathrm{P}, \mathrm{K}$, $\mathrm{Ca}, \mathrm{Co}, \mathrm{Cr}, \mathrm{Fe}, \mathrm{Mg}, \mathrm{Mn}$ and $\mathrm{Ni}$ in plant tissues was determined by inductively coupled plasma optical emission spectrometry (ICP-OES, model Vista-PRO, Varian). To estimate the ability of plants to bioconcentrate $\mathrm{Ni}$ in their aboveground biomass the Bioconcentration Factor (BCF) was calculated as the ratio of the shoot Ni concentration and the total $\mathrm{Ni}$ concentration in the soil. The metal yield (total $\mathrm{Ni}$ phytoextracted) was calculated on the basis of shoot DW yields and shoot Ni concentration for each plant species.

\subsection{Soil analyses}

Both planted and unplanted soil samples were collected at harvest for physico-chemical and microbiological analyses. Composite planted soil samples were obtained by combining the soil around the root ball of each plant (discarding the original plug from the germination tray) per plot during harvesting. For physico-chemical analysis, one part of each composite soil sample was air-dried and sieved to $<2 \mathrm{~mm}$. Soil pH was measured in $\mathrm{H}_{2} \mathrm{O}$ and $0.1 \mathrm{M} \mathrm{KCl}$ at a 1:2.5 (w/v) ratio. Total C and $\mathrm{N}$ were determined by combustion with a CHN analyser (Model CHN1000, LECO Corp., St Joseph, MI). Available P was determined colorimetrically following Olsen's extraction method $\left(0.5 \mathrm{M} \mathrm{NaHCO}_{3}\right.$ adjusted to $\mathrm{pH} 8.2,1: 20 \mathrm{w} / \mathrm{v}$ ). Cation exchange capacity (CEC) was estimated using $1 \mathrm{M} \mathrm{NH}_{4} \mathrm{Cl}(1: 20 \mathrm{w} / \mathrm{v})$ as the sum of exchangeable cations $\mathrm{Ca}, \mathrm{Mg}, \mathrm{Al}, \mathrm{Na}$ and $\mathrm{K}$, determined by ICP-OES. Metal availability was assessed through DTPA-TEA extraction with $0.005 \mathrm{M}$ Diethylene Triamine Pentaacetic Acid (DTPA), $0.01 \mathrm{M} \mathrm{CaCl}_{2}$, and $0.1 \mathrm{M}$ triethanolamine adjusted to pH 7.3 (Lindsay and Norvell, 1978) and measured by ICP-OES.

For soil microbiological analyses, the $<4 \mathrm{~mm}$ fraction of fresh composite soil samples (stored at $+4{ }^{\circ} \mathrm{C}$ ) was used. To determine the culturable bacterial density, $5 \mathrm{~g}$ of soil were shaken for $30 \mathrm{~min}$ in $45 \mathrm{ml}$ sterile sodium hexametaphosphate solution $(1 \%)$. Then, $5 \mathrm{ml}$ of the supernatant were diluted in 10-fold series and plated onto solid 284 culture medium (Schlegel et al., 1961) supplemented with $100 \mu \mathrm{g} \mathrm{ml}^{-1}$ of the fungicide cycloheximide. Medium 284 contains (per litre): $6.06 \mathrm{~g}$ Tris- $\mathrm{HCl}, 4.68 \mathrm{~g} \mathrm{NaCl}, 1.49 \mathrm{~g} \mathrm{KCl}, 1.07 \mathrm{~g} \mathrm{NH}_{4} \mathrm{Cl}, 0.43 \mathrm{~g} \mathrm{Na}_{2} \mathrm{SO}_{4}, 0.2 \mathrm{~g}$ $\mathrm{MgCl}_{2} \cdot 6 \mathrm{H}_{2} \mathrm{O}, 0.03 \mathrm{~g} \mathrm{CaCl}_{2} \cdot 2 \mathrm{H}_{2} \mathrm{O}, 0.04 \mathrm{~g} \mathrm{Na}_{2} \mathrm{HPO}_{4}, 10 \mathrm{~mL} \mathrm{Fe}(\mathrm{III}) \mathrm{NH}_{4}$ citrate solution (containing $48 \mathrm{mg} / 100 \mathrm{ml}$ ) plus oligoelements $(1.5 \mathrm{mg}$ $\mathrm{FeSO}_{4} \cdot 7 \mathrm{H}_{2} \mathrm{O}, 0.3 \mathrm{mg} \mathrm{H} \mathrm{H}_{3}, 0.19 \mathrm{mg} \mathrm{CoCl}{ }_{2} \cdot \mathrm{H}_{2} \mathrm{O}, 0.08 \mathrm{mg} \mathrm{ZnSO}{ }_{4} \cdot 7 \mathrm{H}_{2} \mathrm{O}$, $0.02 \mathrm{mg} \mathrm{CuSO}{ }_{4} \cdot 5 \mathrm{H}_{2} \mathrm{O}, 0.036 \mathrm{mg} \mathrm{Na} 2 \mathrm{MoO} \cdot 2 \mathrm{H}_{2} \mathrm{O}$ ) adjusted to $\mathrm{pH}$. The medium was supplemented with a mixture of different carbon sources: lactate $\left(0.7 \mathrm{~g} \mathrm{~L}^{-1}\right)$, glucose $\left(0.5 \mathrm{gL}^{-1}\right)$, fructose $\left(0.5 \mathrm{gL}^{-1}\right)$ and succinate $\left(0.8 \mathrm{~g} \mathrm{~L}^{-1}\right)$. In order to determine the densities of culturable metaltolerant bacteria, the same dilutions were plated on solid 284 medium supplemented with $2.5 \mathrm{mM} \mathrm{Ni}$ (added as $\mathrm{NiSO}_{4} 6 \mathrm{H}_{2} \mathrm{O}$ ) and cycloheximide. After 7 days of incubation at $28^{\circ} \mathrm{C}$, colony forming units were counted and calculated per gram DW soil (CFUs ${ }^{-1}$ soil).

The community-level physiological profile (CLPP) of the microbial population was performed using Biolog ${ }^{\mathrm{TM}}$ ECO-plates. Each 96-well plate contains 31 different $C$ substrates plus a water control (three replicate each) and the method is based on the ability of microorganisms to oxidise the different $\mathrm{C}$ sources thus obtaining an estimation of the microbial functional diversity. Each well was inoculated with a $150 \mu \mathrm{l}$ aliquot of the $10^{-2}$ soil suspension and plates were incubated in the dark at $28^{\circ} \mathrm{C}$. Colour development in each well was recorded every $24 \mathrm{~h}$ during 7 days by reading the absorbance at $590 \mathrm{~nm}$ using a microplate reader (PowerWave XS2, BioTek Instruments, USA). For each reading time, raw absorbance data were corrected by subtracting the zero hour reading point and the absorbance value given by the control well. The average well colour development (AWCD) was calculated as the sum of the corrected well absorbance values, divided by the 31 carbon sources. Absorbance data were also subdivided into six substrate categories (carbohydrates, carboxylic acids, polymers, amino acids, amines and miscellaneous substrates) to obtain the substrate average well colour development (SAWCD). Substrate richness values (S) represent the number of oxidised substrates and the Shannon's diversity $\left(\mathrm{H}^{\prime}\right)$ and evenness $\left(\mathrm{J}^{\prime}\right)$ indices were calculated using the following formula:

$H^{\prime}=\sum p_{i} \log _{2} p_{i}$

$J^{\prime}=\frac{H^{\prime}}{H_{\max }}$

where $\mathrm{H}_{\max }=\mathrm{H}^{\prime} / \log _{2} \mathrm{~S}$ and $p_{i}$ is the proportional colour development of the $i$ well relative to the total colour development of all wells.

Fluorescein diacetate (FDA) activity was determined following the method described by Adam and Duncan (2001) to estimate the global soil heterotrophic microbial activity. Briefly, $4 \mathrm{ml}$ of tris(hydroxymethyl)aminomethane (THAM; $100 \mathrm{mM}$ ) was added to $1 \mathrm{~g}$ soil and FDA $(0.2 \% \mathrm{w} / \mathrm{v})$ to start the reaction. After $1 \mathrm{~h}$ of incubation at $25^{\circ} \mathrm{C}$, soils were centrifuged $(3 \mathrm{~min} \times 2000 \mathrm{rpm}$ ) and the absorbance in the supernatant was measured at $290 \mathrm{~nm}$ (PowerWave XS2, BioTek Instruments, USA). Soils without FDA substrate were employed as a control.

\subsection{Statistical analysis}

Data were analysed using the IBM SPSS Statistics v.24.0 software. The effects of the fertilisation regime on plant and soil parameters were assessed using a Students $t$-test. In order to determine significant differences amongst plant species and soil parameters of planted and unplanted plots under the same fertilisation regime, a one-way analysis of variance (ANOVA) followed by a multiple comparison of means using the post-hoc Tukey-test for independent means was carried out. Normality of variances was tested by the Kolmogorov-Smirnov test and data were transformed to accomplish normality when necessary.

\section{Results}

\subsection{Soil physico-chemical properties}

Two months after incorporating the compost and before plantation, the mean $\mathrm{pH}$ of the mine-soil was reduced to 6.6 (Table 1) and an increase in available $\mathrm{P}, \mathrm{CEC}$, and $\mathrm{C}$ and $\mathrm{N}$ contents were recorded compared to unamended mine-soil. Total concentrations of the principal metals, $\mathrm{Cr}, \mathrm{Mn}$ and $\mathrm{Ni}$ were significantly lower after compost incorporation, whereas concentrations of $\mathrm{Cu}$ and $\mathrm{Zn}$ (present in the compost) were higher (Table 1). In contrast, DTPA-extractable metal concentrations were increased in the amended mine-soil.

Table 2 shows the changes induced in soil physico-chemical properties by the four hyperaccumulating plant species after 10 months of growth in NPK-fertilised (NPK) and compost-amended (CSS) plots. In the NPK plots, the mean $\mathrm{pH}$ value in non-planted (NP) soil was $7.0 \pm 0.0$, while plant growth led to an increase in $\mathrm{pH}$ which was significant in the case of $O$. muralis and $O$. serpyllifolia $(p<0.05)$. In the CSS plots, soil pH was significantly lower in comparison to NPK, and there were no significant differences between planted and nonplanted (NP) soils (mean pH ranged from 6.4-6.6). Soil C and N contents were significantly higher in compost-amended soils compared to 


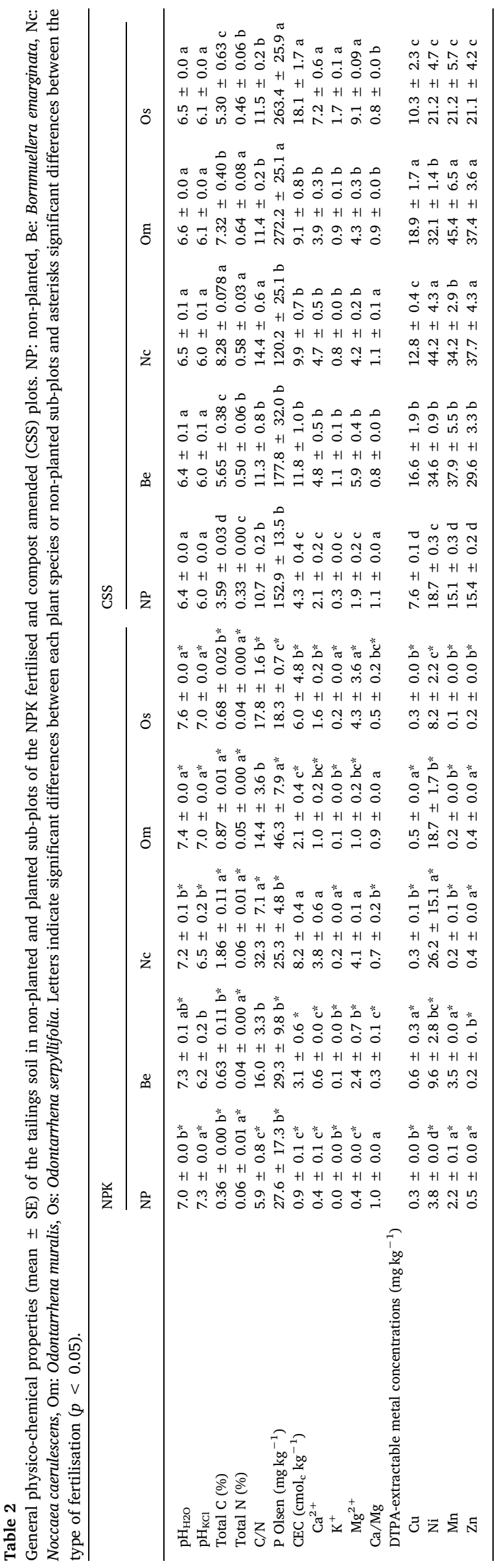

NPK-fertilised soils. Moreover, at harvest the $\mathrm{C}$ and N content of planted soils was significantly higher than NP soil. This was observed in both CSS and NPK plots (except for $\mathrm{N}$ which was only higher in planted soils for CSS). In the CSS plots, a mean value of $3.59 \% \mathrm{C}$ and $0.33 \% \mathrm{~N}$ was found in NP soil, whereas after plant growth these ranged from $5.30-8.28 \%$ C and from $0.46-0.64 \%$ N. In the NPK plots, the mean C content increased from $0.36 \%$ to $0.63-1.86 \%$. In all cases, the highest values were found in soils planted with $O$. muralis and $N$. caerulescens. Plant growth also induced changes in $\mathrm{P}$ availability, and this was more pronounced in the CSS plots and after growth of $O$. muralis and $O$. serpyllifolia: extractable P concentrations were increased by 1.8 - and 1.7-fold $(p<0.05)$. Extractable $\mathrm{P}$ concentrations were consistently lower in the NPK plots than in CSS, but again were significantly higher after cultivating $O$. muralis $(p<0.05)$. Compost addition also enhanced soil CEC: the mean CEC was $0.9 \pm 0.1 \mathrm{cmol}_{\mathrm{c}} \mathrm{kg}^{-1}$ in NPK plots compared to $4.3 \pm 0.4 \mathrm{cmol}_{\mathrm{c}} \mathrm{kg}^{-1}$ in CSS plots (data given for NP soils; $\mathrm{p}<0.05)$. Plant growth led to further increases in CEC. In CSS plots, CEC was increased by 2.1-, 2.3-, 2.7- and 4.0-fold after the growth of $O$. muralis, $N$. caerulescens, $B$. emarginata and $O$. serpyllifolia, respectively $(p<0.05)$. This plant-induced effect was less evident in NPK plots, where only $N$. caerulescens and $O$. serpyllifolia significantly increased soil CEC $(p<0.05)$. In all cases the increase in CEC in planted soils was mainly a result of a plant-induced increase in exchangeable $\mathrm{Ca}$ and Mg (Table 2).

Trace metal availability (DTPA-extractable) was significantly higher in compost-amended plots than NPK-fertilised plots (Table 2). Mean DTPA-extractable $\mathrm{Cu}$ and $\mathrm{Mn}$ concentrations in NP-CSS soils were 26.5and 33.3-fold higher than in the corresponding soils in the NPK plots (Table $2 ; p<0.05$ ). Plant growth led to further increases in DTPAextractable Ni concentrations in both NPK and CSS plots: increments of 2.2- to 6.9-fold and 1.1- to 2.4-fold were observed in NPK and CSS plots, respectively $(p<0.05)$. This effect varied according to plant species, DTPA-extractable Ni concentrations were highest under $N$. caerulescens and lowest under $O$. serpyllifolia in both NPK and CSS plots. Similar plant-induced effects on Mn availability were observed with all plant species but only in the CSS plots; and in this case $O$. muralis had a stronger influence $(p<0.05)$. In contrast, in NPK plots DTPA-extractable Mn concentrations were significantly lower in planted soils than NP soils (except for B. emarginata where no effect was found).

\subsection{Effect of soil amendment on plant survival and biomass production}

After the 10-month growth period, plant survival differed amongst the four species and, with the exception of B. emarginata, it was slightly higher in NPK-fertilised plots. The \% survival for B. emarginata, $N$. caerulescens, O. muralis and O. serpyllifolia was 42, 62, 63 and 40\%, respectively, in NPK plots and 83, 59, 54 and 29\%, respectively, in CSS plots. Fig. 2 shows the shoot dry weight (DW) yields of the four hyperaccumulators grown under the two fertilisation regimes. In NPK plots, biomass production ( $\mathrm{g}$ DW plant ${ }^{-1}$ ) of $B$. emarginata, O. serpyllifolia and $O$. muralis was similar; whereas the mean shoot DW yield for $N$. caerulescens was 12 -fold lower than that obtained with the other three plant species.

Plant growth was significantly enhanced in the CSS plots compared to NPK plots, and this was observed for all plant species $(p<0.05)$. In this case, the shoot DW yields followed the order $O$. muralis $>B$. emarginata $>O$. serpyllifolia $>N$. caerulescens. The most pronounced effect of compost amendment on plant growth was observed for $O$. muralis: shoot DW yields increased from $7.4 \pm 2.9$ to $125.4 \pm 27.6 \mathrm{~g} \mathrm{plant}^{-1}$, representing a 17 -fold increase compared to plants grown in NPK plots $(p<0.05)$. Compost had an intermediate effect on B. emarginata, shoot DW yield was 6.1 -fold higher than that obtained with inorganic fertilisation. Finally, the lowest stimulation in growth was observed for $O$. serpyllifolia and $N$. caerulescens: DW yields increased from 7.3 to $26.7 \mathrm{~g} \mathrm{plant}^{-1}$ (3.6-fold) and from 0.6 to 1.9 g plant $^{-1}$ (3.3-fold), respectively $(\mathrm{p}<0.05)$. Finally, a high 

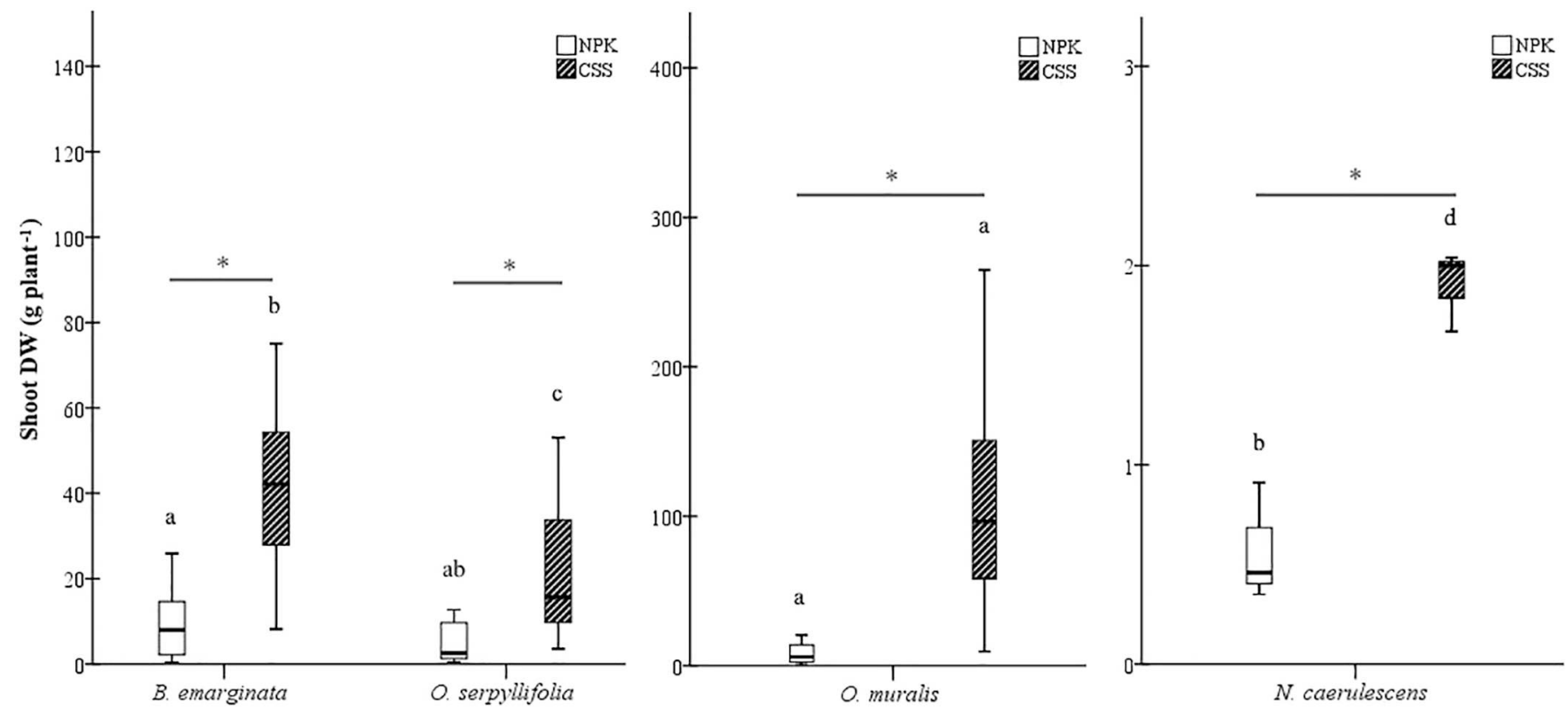

Fig. 2. Effect of fertilisation on the shoot biomass production (mean DW yield per plant \pm SE) of each of the four hyperaccumulators. Median values are represented with a horizontal line within the boxes. Different letters above bars indicate significant differences between plant species growing in the same block (NPK or CSS) and asterisks indicate significant differences between fertilisation regimes within each plant species. Note the graphs use a different y-axis scale.

Table 3

Biomass production, Ni yield and Bioconcentration Factor (BCF, mean \pm SE) for each plant species after the 10-month growth period in NPK fertilised (NPK) and composted sewage sludge (CSS) amended plots. Letters indicate significant differences between plant species and asterisks indicate significant differences between the type of fertilisation to each plant species $(p<0.05)$.

\begin{tabular}{llll}
\hline & Biomass $\left(\mathrm{kg} \mathrm{ha}^{-1}\right)$ & Ni yield $\left(\mathrm{kg} \mathrm{ha}^{-1}\right)$ & $\mathrm{BCF} \times 10^{2}$ \\
\hline B. emarginata & & & \\
$\quad$ NPK & $247.3 \pm 219.9 \mathrm{a}^{*}$ & $2.2 \pm 2.0 \mathrm{a}$ & $40.3 \pm 16.0 \mathrm{a}^{*}$ \\
$\quad$ CSS & $1468.2 \pm 270.8 \mathrm{a}$ & $2.9 \pm 0.5 \mathrm{a}$ & $18.3 \pm 1.5 \mathrm{a}$ \\
N. caerulescens & & & \\
$\quad$ NPK & $82.2 \pm 40.3 \mathrm{a}^{*}$ & $1.5 \pm 1.1 \mathrm{a}$ & $46.3 \pm 30.7 \mathrm{a}^{*}$ \\
$\quad$ CSS & $231.9 \pm 31.6 \mathrm{~b}$ & $1.9 \pm 0.2 \mathrm{a}$ & $11.8 \pm 0.9 \mathrm{a}$ \\
O. muralis & & & \\
$\quad$ NPK & $215.7 \pm 92.9 \mathrm{a}^{*}$ & $0.3 \pm 0.2 \mathrm{a}^{*}$ & $0.5 \pm 0.2 \mathrm{~b}^{*}$ \\
$\quad$ CSS & $2402.0 \pm 343.8 \mathrm{a}$ & $2.3 \pm 0.8 \mathrm{a}$ & $15.8 \pm 0.4 \mathrm{a}$ \\
O. serpyllifolia & & \\
$\quad$ NPK & $194.9 \pm 167.7 \mathrm{a}^{*}$ & $1.0 \pm 1.0 \mathrm{a}$ & $20.1 \pm 15.6 \mathrm{ab}^{*}$ \\
CSS & $462.3 \pm 30.3 \mathrm{~b}$ & $0.7 \pm 0.1 \mathrm{~b}$ & $0.5 \pm 0.0 \mathrm{~b}$ \\
\hline
\end{tabular}

variability in plant biomass was observed amongst plant individuals of $B$. emarginata and $O$. serpyllifolia in NPK plots, and of $B$. emarginata and O. muralis in CSS plots (Table 3).

\subsection{Effect of soil amendment on shoot Ni concentration, Ni yield and bioaccumulation}

In NPK plots, shoot Ni concentrations varied significantly amongst the four plant species, but also amongst plant individuals of the same species (Fig. 3). Bornmuellera emarginata presented the highest shoot $\mathrm{Ni}$ concentrations (with a mean of $6174 \pm 1692 \mathrm{mg} \mathrm{kg}^{-1}$ ) and $O$. muralis the lowest (with a mean of $1140 \pm 381 \mathrm{mg} \mathrm{kg}^{-1}$ ). $N$. caerulescens and $O$. serpyllifolia accumulated intermediate concentrations, with mean concentrations of $3627 \pm 1264$ and $3520 \pm 2078 \mathrm{mg} \mathrm{kg}^{-1}$, respectively (Fig. 3). Compost addition induced a substantial reduction in shoot $\mathrm{Ni}$ concentration in all plant species except $O$. muralis: shoot $\mathrm{Ni}$ concentrations were significantly decreased by 3.3-, 2.5- and 1.8-fold in B. emarginata, $N$. caerulescens and O. serpyllifolia, respectively (Fig. 3). A similar trend was observed for plant Ni yields, which decreased in

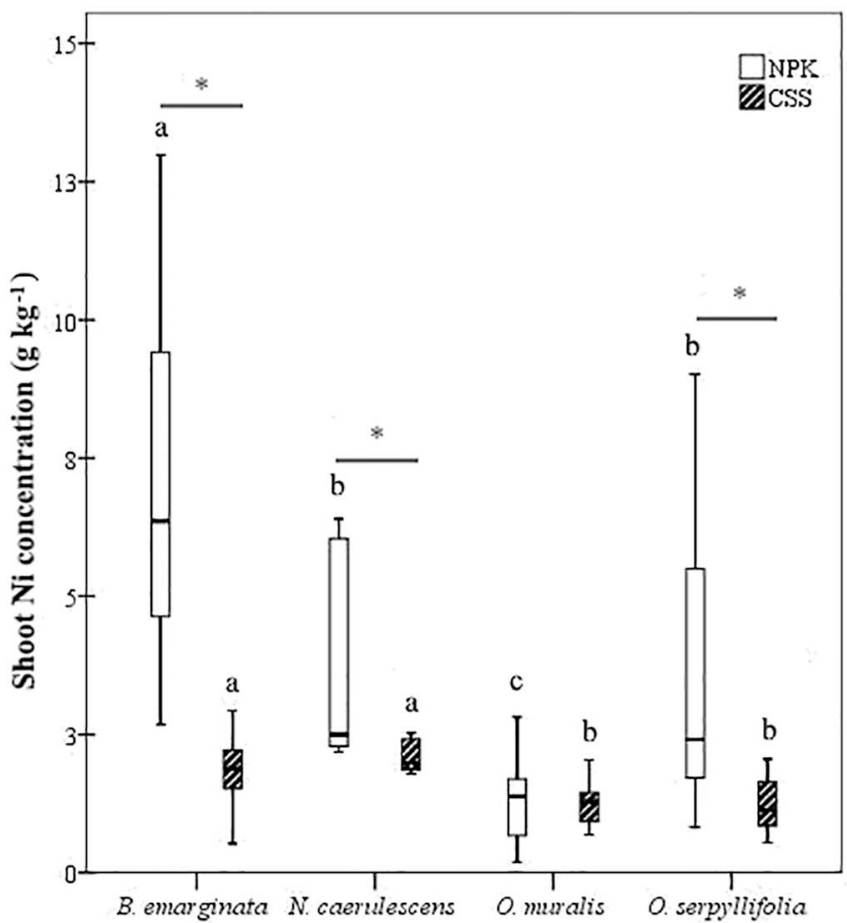

Fig. 3. Shoot Ni concentration (mean \pm SE) of plants grown in the inorganic (NPK)- or compost (CSS)- amended plots. Median values are represented with a horizontal line within the boxes. Letters indicate significant differences between plant species with each fertilisation regime, and asterisks between the type of fertilisation within each plant species.

NPK plots in the following order: B. emarginata $>N$. caerulescens $>0$. serpyllifolia $>$ O. muralis (Table 3). The mean Ni yield of $O$. muralis was increased by 7.7-fold when this species was grown in CSS plots compared to NPK plots $(p<0.05)$, reaching values equivalent to $2.3 \mathrm{~kg} \mathrm{Ni}$ $\mathrm{ha}^{-1}$. The same was observed, but to a lesser extent, with $B$. emarginata and $N$. caerulescens. In contrast, a 1.4-fold decrease in Ni yield of $O$. serpyllifolia was obtained when this hyperaccumulator was grown in 
Table 5

Colony forming units per gram fresh soil (CFUs * $10^{6} \mathrm{~g}^{-1} \pm \mathrm{SE}$ ) in planted and non-planted soils of the NPK fertilised (NPK) and the compost amended (CSS) plots and the ratio planted to non-planted plots (P/NP). Letters indicate significant differences between planted or non-planted sub-plots under the same fertilisation regime and asterisks indicate differences between the type of fertilisation (NPK or CSS) to each plant planted or non-planted sub-plots $(p<0.05)$.

\begin{tabular}{|c|c|c|c|c|}
\hline & \multicolumn{2}{|l|}{284} & \multicolumn{2}{|l|}{$\mathrm{Ni} 2.5 \mathrm{mM}$} \\
\hline & CFUs $* 10^{6}$ & $\mathrm{P} / \mathrm{NP}$ & CFUs $* 10^{6}$ & $\mathrm{P} / \mathrm{NP}$ \\
\hline \multicolumn{5}{|c|}{ Non-planted } \\
\hline NPK & $1.9 \pm 0.1 b$ & & $0.1 \pm 0.0 \mathrm{~b}$ & \\
\hline CSS & $2.7 \pm 0.2 \mathrm{~b}$ & & $0.1 \pm 0.0 \mathrm{~b}$ & \\
\hline \multicolumn{5}{|c|}{ Bornmuellera emarginata } \\
\hline NPK & $5.4 \pm 2.7 b$ & $2.8 \mathrm{a}$ & $0.6 \pm 0.1 \mathrm{ab}$ & $5.2 \mathrm{~b}^{*}$ \\
\hline CSS & $10.2 \pm 2.4 \mathrm{a}$ & $3.7 \mathrm{~b}$ & $0.9 \pm 0.2 \mathrm{ab}$ & $8.5 \mathrm{~b}$ \\
\hline \multicolumn{5}{|c|}{ Noccaea caerulescens } \\
\hline NPK & $11.2 \pm 1.7 \mathrm{a}^{*}$ & $5.8 \mathrm{a}^{*}$ & $0.7 \pm 0.0 \mathrm{a}^{*}$ & $5.7 b^{*}$ \\
\hline CSS & $19.1 \pm 3.6 \mathrm{a}$ & $7.0 \mathrm{a}$ & $1.7 \pm 0.2 \mathrm{a}$ & $15.2 \mathrm{a}$ \\
\hline \multicolumn{5}{|c|}{ Odontarrhena muralis } \\
\hline NPK & $7.0 \pm 2.0 \mathrm{a}^{*}$ & $3.6 \mathrm{a}$ & $1.2 \pm 0.8 \mathrm{a}^{*}$ & $10.1 \mathrm{a}^{*}$ \\
\hline CSS & $12.3 \pm 2.8 \mathrm{a}$ & $4.5 \mathrm{~b}$ & $0.3 \pm 0.1 \mathrm{~b}$ & $3.2 \mathrm{~b}$ \\
\hline \multicolumn{5}{|c|}{ Odontarrhena serpyllifolia } \\
\hline NPK & $7.7 \pm 1.9 \mathrm{a}^{*}$ & $4.0 \mathrm{a}^{*}$ & $1.2 \pm 0.0 \mathrm{a}$ & $10.2 \mathrm{a}$ \\
\hline CSS & $26.8 \pm 2.9 \mathrm{a}$ & $9.8 \mathrm{a}$ & $1.7 \pm 0.7 \mathrm{a}$ & $15.6 \mathrm{a}$ \\
\hline
\end{tabular}

CSS plots ( $p>0.05$; Table 3).

Finally, B. emarginata, $N$. caerulescens and $O$. serpyllifolia presented elevated BCF values when grown in the NPK-fertilised plots, ranging from 20.1 (O. serpyllifolia) to up to 46.3 ( $N$. caerulescens). In contrast, $\mathrm{BCF}$ values for these species were 2.2-, 3.9- and 20.1-fold lower when grown in compost-amended plots (Table 3 ). The opposite was observed in the case of $O$. muralis: the BCF of this species was 31.6-fold higher when grown in compost-amended soil compared to NPK fertilisation (Table 3).

\subsection{Effect of soil amendment on plant nutrients}

Some differences in shoot ionome were observed between plants grown in soils amended with compost or fertilised with inorganic NPK (Table 4). Compost amendment led to significant increases in shoot $\mathrm{P}$ and $\mathrm{K}$ concentrations in all plant species (except for $N$. caerulescens in the case of $\mathrm{K}$ ) compared to NPK fertilisation $(p<0.05)$. In contrast, shoot Ca concentration was reduced by 1.2 - and 1.3 -fold in $O$. muralis and $O$. serpyllifolia $(p<0.05)$ in CSS plots compared to NPK plots, whereas no differences in this element were observed in B. emarginata and $N$. caerulescens. All plant species except $O$. muralis, presented significantly lower shoot $\mathrm{Mg}$ concentrations in CSS plots $(p<0.05)$. In accordance, amending with compost tended to increase the shoot $\mathrm{Ca} /$ $\mathrm{Mg}$ quotient, although this was only significant for $O$. serpyllifolia $(p<0.05)$. The Odontarrhena species presented the highest $\mathrm{Ca} / \mathrm{Mg}$ quotient in both NPK and CSS plots.

A generalized effect of compost amendment on shoot micro-nutrient concentrations was observed in all four hyperaccumulators (Table 4). Shoot $\mathrm{Mn}, \mathrm{Cu}$ and $\mathrm{Zn}$ concentrations were consistently and significantly higher in all plants grown in CSS plots, and shoot Co concentration in shoots of $N$. caerulescens and $O$. muralis $(\mathrm{p}<0.05)$. On the other hand, the compost amendment tended to reduce shoot Fe concentration in $N$. caerulescens, $O$. serpyllifolia and $O$. muralis (significant in case of the first two species). In CSS plots, $N$. caerulescens presented notably higher concentrations of $\mathrm{Fe}$ and $\mathrm{Zn}$ than any of the other three species (Table 4). For example, a mean concentration of $1564 \pm 276 \mathrm{mg} \mathrm{Zn} \mathrm{kg}^{-1}$ was recorded, whereas in the other species this ranged from $152 \pm 2 \mathrm{mg} \mathrm{Zn} \mathrm{kg}^{-1}$ in $O$. muralis to $31 \pm 12 \mathrm{mg} \mathrm{Zn} \mathrm{kg}^{-1}$ in O. serpyllifolia. 
Table 6

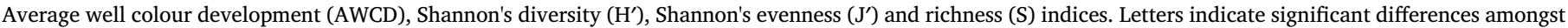

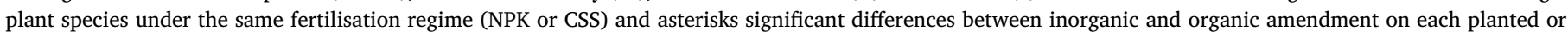
unplanted sub-plots $(p<0.05)$.

\begin{tabular}{|c|c|c|c|c|}
\hline & AWCD & $\mathrm{H}^{\prime}$ & $J^{\prime}$ & $S$ \\
\hline \multicolumn{5}{|c|}{ Non-planted } \\
\hline NPK & $0.61 \pm 0.01 \mathrm{~b} *$ & $3.38 \pm 0.01 b^{*}$ & $0.73 \pm 0.02 b^{*}$ & $25.0 \pm 1.3 \mathrm{~b}^{*}$ \\
\hline CSS & $2.06 \pm 0.02 \mathrm{~b}$ & $4.84 \pm 0.02 \mathrm{a}$ & $1.02 \pm 0.03 \mathrm{~b}$ & $27.0 \pm 1.2 \mathrm{a}$ \\
\hline \multicolumn{5}{|c|}{ B. emarginata } \\
\hline NPK & $1.69 \pm 0.09 \mathrm{a} *$ & $4.69 \pm 0.12 \mathrm{a}$ & $0.99 \pm 0.03 \mathrm{a}$ & $27.0 \pm 3.0 \mathrm{a}$ \\
\hline CSS & $2.31 \pm 0.04 \mathrm{a}$ & $4.93 \pm 0.01 \mathrm{a}$ & $1.02 \pm 0.00 \mathrm{a}$ & $29.3 \pm 1.3 \mathrm{a}$ \\
\hline \multicolumn{5}{|c|}{ N. caerulescens } \\
\hline NPK & $1.64 \pm 0.16 \mathrm{a} *$ & $4.87 \pm 0.19 a$ & $1.01 \pm 0.02 \mathrm{a}$ & $29.0 \pm 1.2 \mathrm{a}$ \\
\hline CSS & $2.32 \pm 0.10 \mathrm{a}$ & $4.91 \pm 0.01 \mathrm{a}$ & $1.02 \pm 0.00 \mathrm{a}$ & $29.0 \pm 1.5 \mathrm{a}$ \\
\hline \multicolumn{5}{|c|}{ O. muralis } \\
\hline NPK & $1.87 \pm 0.15 \mathrm{a}$ & $4.68 \pm 0.09 a$ & $0.95 \pm 0.09 a$ & $27.7 \pm 1.7 \mathrm{a}$ \\
\hline CSS & $2.16 \pm 0.03 \mathrm{ab}$ & $4.93 \pm 0.05 a$ & $1.00 \pm 0.01 \mathrm{a}$ & $29.0 \pm 1.7 \mathrm{a}$ \\
\hline \multicolumn{5}{|c|}{ O. serpyllifolia } \\
\hline NPK & $1.40 \pm 0.02 \mathrm{a} *$ & $4.60 \pm 0.10 a^{*}$ & $0.97 \pm 0.03 \mathrm{a}$ & $27.0 \pm 1.0 \mathrm{a}$ \\
\hline CSS & $2.30 \pm 0.03 a$ & $4.93 \pm 0.01 \mathrm{a}$ & $1.01 \pm 0.01 \mathrm{a}$ & $29.3 \pm 1.3 \mathrm{a}$ \\
\hline
\end{tabular}

\subsection{Effect of soil amendment on soil microbial parameters}

The densities of culturable bacteria associated with the four hyperaccumulators and non-planted (NP) soils are presented in Table 5. Bacterial densities in NP soil did not differ significantly between NPKfertilised and compost-amended plots, ranging from $1.9 \times 10^{6} \mathrm{CFUs}^{-1}$ soil in the NPK plot to $2.7 \times 10^{6} \mathrm{CFUs}^{-1}$ soil in the CSS plot. In these soils, Ni-tolerant bacteria represented 6.0 and $4.0 \%$ of the total culturable population, respectively. All plant species grown in CSS plots harboured a higher bacterial density compared to the same species in NPK plots $(p<0.05)$. In addition, a plant-species specific effect was observed in both NPK and CSS plots: $N$. caerulescens and $O$. serpyllifolia harboured the highest bacterial densities whereas the lowest were observed for $B$. emarginata. The plant-induced stimulation in bacterial densities is also reflected by the $\mathrm{P} / \mathrm{NP}$ ratios (Table 5). In addition, planted soils (both in NPK and CSS plots) harboured higher densities of Ni-tolerant bacteria compared to NP soils, although this increase was not always significant. The Odontarrhena species harboured the highest proportion of Ni-tolerant bacteria when grown in NPK plots, representing $16.6 \%$ and $15.1 \%$ of the total culturable population, followed by $B$. emarginata $(10.8 \%)$. However, the same was not observed in CSS plots, where the proportion of Ni-tolerant bacteria in relation to the total culturable population was lower, especially in the case of $O$. muralis (3.5\%).

The overall functional activity of the soil heterotrophic microbial community was evaluated by FDA activity and the AWCD values obtained from Biolog Ecoplates. Compost-amended soils presented significantly higher microbial activity (on the basis of AWCD) in both planted (except $O$. muralis) and NP soils compared to corresponding NPK-fertilised soils (Table 6). Mean AWCD in NP plots increased by 3.3fold in the presence of organic amendment, while in planted plots this increase ranged from 1.2- to 1.6-fold. Within planted soils, AWCD did not differ significantly amongst the four hyperaccumulating plant species. The Shannon's diversity $\left(\mathrm{H}^{\prime}\right)$, Shannon's evenness $\left(\mathrm{J}^{\prime}\right)$ and richness (S) indices are given in Table 6. Compost amendment led to an increase in $\mathrm{H}^{\prime}$ and $\mathrm{J}^{\prime}$ values in comparison with inorganic fertilisation, and this was significant for NP soils (both $\mathrm{H}^{\prime}$ and $\mathrm{J}^{\prime}$ ), and for $O$. serpyllifolia $\left(\mathrm{H}^{\prime}\right)$. Also, increases in $\mathrm{H}^{\prime}$ values were observed in planted soils, and this was especially pronounced in NPK plots. The same trend was observed in evenness $\left(\mathrm{J}^{\prime}\right)$ values obtained in NPK plots. No significant differences were observed amongst the different plant species for either $\mathrm{H}^{\prime}$ or $\mathrm{J}^{\prime}$ indices.

In addition to the increase in AWCD, a higher number of $C$ substrates were utilised in CSS plots compared to NPK plots (S values, $p<0.05$; Table 6). Plant growth also stimulated the functional diversity of the soil microbial communities, as reflected by the higher numbers of metabolised C substrates in planted soils compared to NP soils. This plant-induced effect was observed in both NPK and CSS plots. However, few differences in $S$ values were observed amongst the four plant species.

Fig. 4 shows the substrate average colour development (SAWCD) of the microbial community associated with the different plant species and NP soils. SAWCD values were highest for carbohydrates, amines and polymers in both NPK and CSS plots, corresponding with more than $50 \%$ of the metabolised C sources. Amending with compost led to shifts in the $C$ source utilisation patterns. SAWCD values were higher in compost-amended soils (both NP and planted) compared to NPK-soils, and this was particularly pronounced for amines and in some cases carboxylates $(p<0.05)$. A pronounced difference in SAWCD values was observed between NP and planted soils in the NPK plots, irrelevant of the species. For example, a significant increase in the use of amines was observed in the presence of all four hyperaccumulators, and in carboxylates in the presence of B. emarginata and O. muralis (Fig. 4). In contrast, with a few exceptions $C$ type usage patterns were similar for both planted and NP soils of the CSS plots (Fig. 4). In these plots, a significant increase in the metabolism of amines was observed after growth of the hyperaccumulators $B$. emarginata and $N$. caerulescens (Fig. 4).

Likewise, FDA hydrolase activity was significantly higher in compost-amended soils compared to NPK soils, and this was the case for both planted and NP soils ( $\mathrm{p}<0.05$ ) (Fig. 5). In some cases, plant growth led to further increases in FDA activity compared to NP subplots $(p<0.05)$. A mean FDA activity of $5.2 \pm 0.1 \mu \mathrm{g} \mathrm{g}^{-1}$ soil h$^{-1}$ was recorded in NP soils of the NPK plots, and this increased to $9.6 \pm 0.5 \mu \mathrm{gg}^{-1}$ soil $\mathrm{h}^{-1}$ and $18.9 \pm 0.1 \mu \mathrm{gg}^{-1}$ soil $^{-1}$ in soils under $N$. caerulescens and $O$. muralis, respectively ( $\mathrm{p}<0.05$ ). In CSS plots, FDA activity was stimulated in soils under $B$. emarginata and $N$. caerulescens, increasing from a mean value of $29.7 \mu \mathrm{g} \mathrm{g}^{-1} \mathrm{soil} \mathrm{h}^{-1}$ in NP soils to $42.5-45.7 \mu \mathrm{g} \mathrm{g}^{-1}$ soil h$^{-1}$ (Fig. 5).

\section{Discussion}

The mine spoil soil was deficient in essential nutrients and organic matter, and presented high concentrations of $\mathrm{Ni}, \mathrm{Mn}$ and $\mathrm{Cr}$, as was previously shown for this site (Ghasemi et al., 2018a). Compared to the natural serpentine soils of the Melide ultramafic complex, which are in the same region as the quarry (Álvarez-López et al., 2016b; Ghasemi et al., 2018b), the mine-soil $\mathrm{pH}$ is significantly higher, while the $\mathrm{C} / \mathrm{N}$ ratio and CEC are lower. Nutrient availability, including $\mathrm{P}$ and $\mathrm{K}$, are also minimal. On the other hand, the presence of carbonates in the 

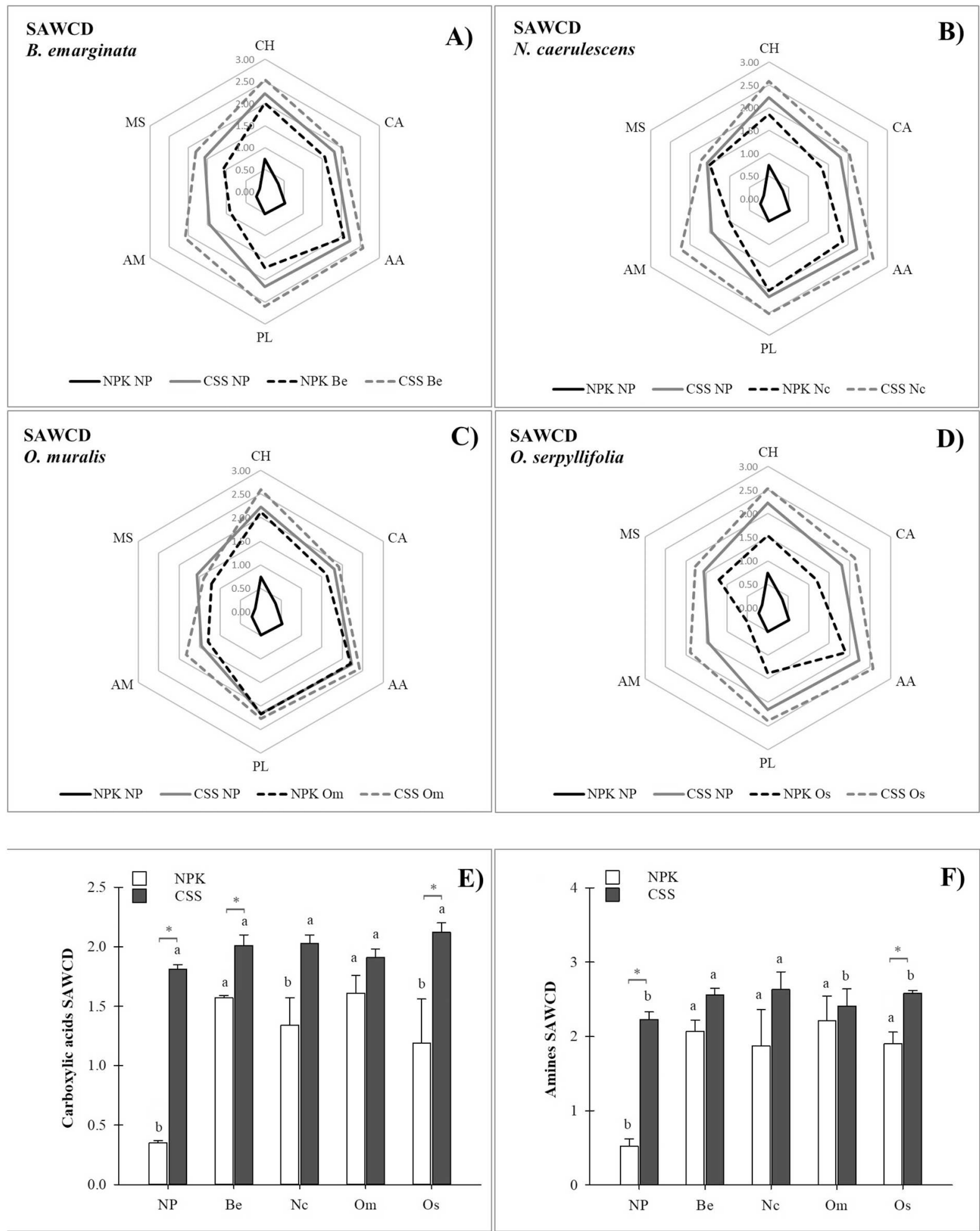

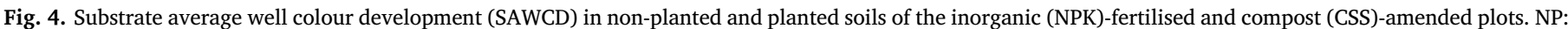

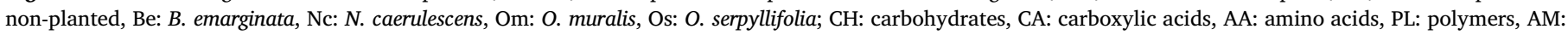
amines, MS: miscellaneous. 


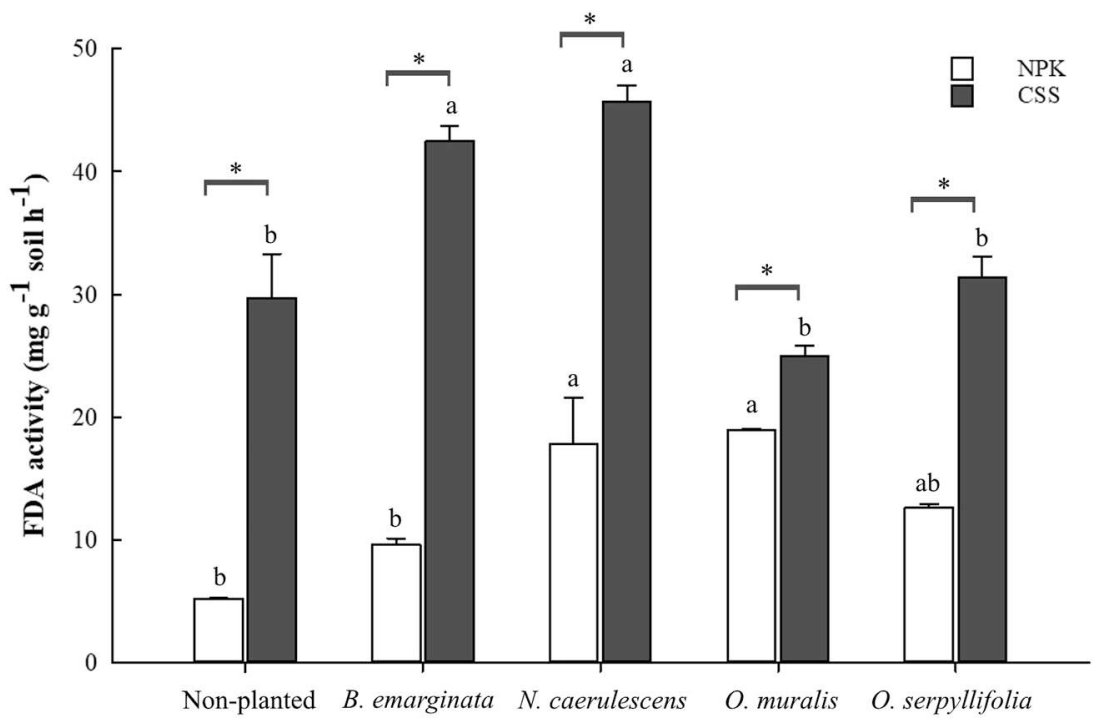

Fig. 5. FDA activity in planted or non-planted soils of the inorganic (NPK)- and compost (CSS)-amended plots (mean $\pm \mathrm{SE}$ ). Letters indicate significant differences between plant species or non-planted soils under the same fertilisation regime and asterisks significant differences between the type of fertilisation within each plant species or non-planted soil $(p<0.05)$. parent material results in a more balanced Ca:Mg ratio than that usually found in these natural serpentine soils. Although the pseudo-total Ni concentrations are comparable to those recorded in the natural serpentine soils from the region, $\mathrm{Ni}$ availability in the spoil (estimated using DTPA-extractable concentrations) is up to two magnitudes lower (mean DTPA-extractable $\mathrm{Ni}$ was $3.8 \mathrm{mg} \mathrm{kg}^{-1}$ compared to close to $100 \mathrm{mg} \mathrm{kg}^{-1}$; Ghasemi et al., 2018b).

Improving the physical, chemical and biological properties of the mine-soil is necessary for plant establishment and development. The improvement in soil fertility through the addition of inorganic NPK fertilisers has been shown to be effective for enhancing the growth of hyperaccumulating plants in natural serpentine soils (Bani et al., 2015a; Li et al., 2003), but organic amendments can also overcome soil physical deficiencies such as the poor structure and porosity and limited water retention capacity (Álvarez-López et al., 2016b; Ghasemi et al., 2018b) and positively influence soil microbial activity (Benbi et al., 2017). Here, the addition of the composted sewage sludge also improved mine-soil $\mathrm{pH}$ for hyperaccumulator growth. At the end of the field experiment, $\mathrm{pH}$ values in the unplanted CSS plots were within the optimal range defined for Ni phytoextraction by Odontarrhena species (pH 5-6.5) (Nkrumah et al., 2016) and were maintained after plant growth with no significant differences amongst plant species. The improvements in soil fertility (increase in $P$ availability and exchangeable $\mathrm{Ca}$ and $\mathrm{K}$ ) were reflected in the shoot ionome of plants growing in CSS plots. Shoot concentrations of most macro- and micro-nutrients were in the range found for Odontarrhena spp., Noccaea spp. and B. emarginata, growing in Mediterranean ultramafic areas (Bani et al., 2010) or natural serpentine soil from the quarry region (Álvarez-López et al., 2016a; Pardo et al., 2018). In contrast, shoot Fe concentrations decreased in all the hyperaccumulating species (except $B$. emarginata) in the CSS plots, which could be the result of complexation with the organic matter (Lützow et al., 2006). It is worth noting the elevated shoot Fe concentrations found in $N$. caerulescens when grown in both NPK and CSS plots, which may reflect a high capacity of this population to bioaccumulate Fe.

DTPA-extractable concentrations of $\mathrm{Cu}, \mathrm{Mn}, \mathrm{Ni}$ and $\mathrm{Zn}$ were significantly higher in the CSS plots compared to NPK plots. In the case of $\mathrm{Cu}, \mathrm{Mn}$ and $\mathrm{Zn}$, these elements originate from the compost itself (Table 1), while this is not the case for $\mathrm{Ni}$ (total Ni concentrations in the compost were $<40 \mathrm{mg} \mathrm{kg}^{-1}$ ). However, in all cases further increases in the availability of these metals were observed after plant growth. These results are in agreement with those of Ghasemi et al. (2018a) who used the same mine-soil in a pot experiment with different Odontarrhena spp. (including $O$. serpyllifolia). However, they contrast with other authors who have found significant reductions in the $\mathrm{Ni}$ availability in natural serpentine soils after amendment with composted sewage sludge (the same compost as this study) (Álvarez-López et al., 2016a). The increase in Ni availability after the incorporation of compost was likely due to the weathering activity of labile C compounds (e.g. carboxylic acids) present in the compost on the Ni-rich minerals and release of labile Ni. Several authors have shown an increase in soil metal availability in the rhizosphere of hyperaccumulating plants, such as those belonging to the genera Odontarrhena (Ghasemi et al., 2018b; Kidd et al., 2009) and Noccaea (Puschenreiter et al., 2005; Wenzel et al., 2003). This is generally related to the presence of carboxylic acid anions (such as oxalate) or simple phenolics present in the root exudates which are released into the rhizosphere (Kidd et al., 2009). ChardotJacques et al. (2013) found that the growth of the Ni-hyperaccumulator Leptoplax emarginata (syn. B. emarginata) increased the dissolution of chrysotile, a silicate from the serpentine group with low $\mathrm{Ni}$ availability. These authors suggested that the high Ni uptake by the plant causes a decrease in water-soluble $\mathrm{Ni}$ which in turn induces chrysotile dissolution. More recently, these phenomena have been connected to the activity of plant-associated bacteria on metal speciation and bioavailability (Kidd et al., 2017).

Pseudo-total $\mathrm{Zn}$ concentrations in the mine-soil were in the range for normal soils (Kabata-Pendias and Pendias, 2001) but were increased by 6.2-fold after the addition of the compost, and DTPA-extractable Zn concentrations were also 45.7-fold higher. Noccaea caerulescens presented particularly elevated shoot $\mathrm{Zn}$ concentrations in these plots (mean concentration of $1565 \mathrm{mg} \mathrm{Zn} \mathrm{kg}^{-1}$ ) compared to the other plant species (one order of magnitude higher). Individuals of this population of $N$. caerulescens growing naturally in the surrounding area of the quarry also show elevated $\mathrm{Zn}$ accumulation (shoot concentrations ranging from 320 to $1450 \mathrm{mg} \mathrm{Zn} \mathrm{kg}^{-1}$ ) at the same time as Ni hyperaccumulation (4500-18,700 $\mathrm{mg} \mathrm{Ni} \mathrm{kg}^{-1}$ ), despite low pseudo-total and available $\mathrm{Zn}$ concentrations ( $<100 \mathrm{mg} \mathrm{kg}^{-1}$; unpublished results). In addition, growth of $N$. caerulescens (together with $O$. muralis) led to the highest stimulation in soil $\mathrm{Zn}$ availability. Other authors have found that several Noccaea spp., including $N$. caerulescens, are able to accumulate Zn from Zn-rich soils but also from soils containing "normal" concentrations of this element (Bani et al., 2010; Reeves et al., 2001). It would be interesting to further evaluate the $\mathrm{Zn}$ accumulation capacity of the population of $N$. caerulescens used in this study in $\mathrm{Zn}$-enriched soils.

Compared to natural serpentine soils in this region, culturable bacterial densities and metabolic activity and diversity of the mine-soil microbial community was low (Álvarez-López et al., 2016a; Pardo 
et al., 2018), confirming the unfavourable conditions for microbial growth in these substrates. The input of nutrients and labile $\mathrm{C}$ present in the compost stimulated the microbial activity and diversity. These results coincide with previous studies showing improvements in soil physico-chemical and biological properties of mine-soils after addition of organic residues (Garaiyurrebaso et al., 2017; Pardo et al., 2014). As expected, planted soils always harboured higher bacterial densities than NP soils. This plant effect is likely due to the release of labile $\mathrm{C}$ and growth factors present in the root exudates, which was generally more pronounced in CSS plots where plant root growth and proliferation were enhanced. Noccaea caerulescens and O. serpyllifolia harboured higher bacterial densities under both fertilisation regimes (highest P/ NP ratios). This could partly be attributed to the fact that these plant species are naturally found growing in natural serpentine soils of the region, whereas the other two plant species are native to the Mediterranean region. It is well recognised that the size and composition of bacterial communities associating with hyperaccumulators is plant species-specific but also differs amongst different populations belonging to the same species (Álvarez-López et al., 2016a). The incorporation of the amendment and the presence of plants had a strong effect on the overall functional activity of soil microbiota, as assessed with the Biolog-CLPP parameters and FDA activity. The AWCD and FDA values were increased by 3- to 6-fold in NP soil of CSS plots compared to NPK plots. Plants led to further increases in both soil microbial densities and activity. The FDA activity was substantially higher in the soil under $B$. emarginata and $N$. caerulescens, despite the lower bacterial densities associated with the former plant species. Increased soil hydrolytic capacity has been related to a higher soil $\mathrm{C}$ content and number of metabolically active microorganisms (Benbi et al., 2017). In agreement, the soils associated with these two plant species also showed the highest $\mathrm{C}$ content as well as AWCD values. Furthermore, a generalized effect of all plant species was found on the number of $C$ substrates utilised (the metabolic richness, $\mathrm{S}$ ) and the diversity in the use of these $\mathrm{C}$ substrates (indicated by the $\mathrm{H}^{\prime}$ index). The presence of elevated concentrations of metals in contaminated or metalliferous soils exerts selective pressure on soil microorganisms, and strongly influences the composition of the microbial community (Burges et al., 2016; Harantová et al., 2017). The addition of the compost may have a protective effect on the microorganisms from the unfavourable abiotic conditions of the mine-soil, which could explain the decrease in densities of Ni-tolerant bacteria in the CSS plots compared to NPK plots. However, despite the higher proportion of Ni-resistant bacteria in NPK soils, the compost-amended soil also showed elevated P/NP ratios (except for $O$. muralis). Several authors have found a positive correlation between the presence of hyperaccumulator plants and the bacterial density or relative gene abundance of metal-resistant bacteria in soil; this was the case for $N$. caerulescens and $O$. serpyllifolia, and for various metals, including $\mathrm{Ni}, \mathrm{Zn}$ and Cd (Álvarez-López et al., 2016a; Epelde et al., 2010; Mengoni et al., 2010). Since plant-associated bacteria can influence metal mobility and availability in soils, as well as promote a higher tolerance and biomass production, studying the microbial communities in such mine spoils could be useful for identifying bioinoculants within the context of optimising the Ni phytomining strategy.

Plant survival varied considerably amongst replicate plots of the same species and under the same fertilisation regime. Surprisingly, it was not significantly enhanced after compost addition (with the exception of B. emarginata). Data obtained from the nearest meteorological station (Lalín, NW Spain) showed that the Spring and Summer of 2017 was characterised for being extremely warm and dry. Registered precipitation in April was 83\% lower than the normal values for this region and season. In May, maximal temperatures of $36.2^{\circ} \mathrm{C}$ were recorded, with daily oscillations of up to $30.7^{\circ} \mathrm{C}$. During the whole experimental period (September 2016 to July 2017) the mean temperature was $11.7^{\circ} \mathrm{C}$, with a fluctuation between $+37.4^{\circ} \mathrm{C}$ and $-6.5{ }^{\circ} \mathrm{C}$, and an accumulated precipitation of $8191 \mathrm{~m}^{-2}$. In accordance, the plants were affected both by late frosts and extreme drought, which accounts for the high mortality rates in some species. Unexpectedly, the highest plant mortality was observed for the native O. serpyllifolia, which is adapted to the natural serpentine soils in this region: plant survival did not reach $50 \%$ in either the NPK or CSS plots for this species. In greenhouse pot experiments, despite limited growth, no mortality was observed in this species when grown in the same mine-soil (Ghasemi et al., 2018a).

Nonetheless, the positive effects of compost addition on soil quality (discussed above) were clearly reflected in the stronger growth and healthier aspect of all plant species in the CSS plots. Plants responded dramatically to organic amendment with greatly improved shoot DW yields. Best response in terms of biomass production was obtained for the hyperaccumulators $O$. muralis and $B$. emarginata, where the mean biomass yields were equivalent to 2402 and $1468 \mathrm{~kg} \mathrm{ha}^{-1}$, respectively. Both these Mediterranean plant species have been recognised for their potential application in nickel agromining in Albanian ultramafic soils (van der Ent et al., 2015). This study suggests that they are also good candidates for developing phytomining activities in degraded Ni-enriched mine-soils. However, in contrast to this positive response in biomass production, amending the mine-soil with compost led to significant reductions in shoot $\mathrm{Ni}$ concentrations. This was the case for all plant species except $O$. muralis, which reinforces the suitability of this species in the phytomining technique. Similar reductions in shoot $\mathrm{Ni}$ concentrations have been observed in greenhouse studies for several hyperaccumulating plant species when grown in natural serpentine soils amended with organic matter (Álvarez-López et al., 2016b) but also in spoil soils from the same quarry as the present study (Ghasemi et al., 2018a). These authors also observed a reduction in the BCF values after compost addition in several species of Odontarrhena (including O. serpyllifolia) and Noccaea; in all cases the reduction in BCF was proportional to the rate of addition. In this study, an increase in the BCF after compost addition was only observed for $O$. muralis, confirming the higher capacity of this species to extract and accumulate $\mathrm{Ni}$ in the shoots compared to the other plant species. The reduction in shoot Ni concentration could be due to a dilution effect since the promotion in plant biomass was not mirrored by a reduction in soil $\mathrm{Ni}$ availability (DTPA-extractable).

Despite the reductions in shoot $\mathrm{Ni}$ concentrations observed in $B$. emarginata and $N$. caerulescens grown in the compost-amended plots, the stimulation in shoot DW biomass led to significantly higher $\mathrm{Ni}$ yields. In the case of $O$. serpyllifolia, although the biomass of this species was enhanced with the compost the shoot $\mathrm{Ni}$ concentration was strongly reduced, resulting in a lower Ni yield in the CSS soil. Finally, shoot $\mathrm{Ni}$ concentrations of $\mathrm{O}$. muralis were the lowest compared to the other three plant species; however, due to the strong response in this species to compost addition the overall Ni yield was close to that obtained with B. emarginata. Similarly, Chardot et al. (2005) found in a pot experiment using three different soils that $B$. emarginata accumulated $\mathrm{Ni}$ concentrations as high as $N$. caerulescens and $O$. muralis but produced a higher biomass. In a one-year agromining trial using these two hyperaccumulating plant species, and carried out in natural soils of the same serpentine outcrop as the quarry, the total biomass harvested was $996 \mathrm{~kg} \mathrm{ha}^{-1}$ and $679 \mathrm{~kg} \mathrm{ha}^{-1}$ for O. muralis and B. emarginata, respectively (Pardo et al., 2018). The biomass production at the quarry site was therefore $>2$-fold higher than that obtained in these natural soils. Although the authors of the latter study pointed out that the biomass yields obtained were low due to adverse climate and growth conditions: elevated precipitation which resulted in soil waterlogging, together with competition from proliferating weeds, led to significant plant mortality. In contrast, in the study of Pardo et al. (2018), shoot $\mathrm{Ni}$ concentrations of $O$. muralis were 3.8- and 3.2- fold higher than those obtained for $O$. muralis in the NPK and the CSS plots, respectively, and 0.7- and 2.2-fold higher in the case of B. emarginata (in NPK and CSS, respectively). Bani et al. (2015a) conducted a field study evaluating the performance of $O$. muralis for extensive phytomining in the ultramafic area of Pojskë (Pogradec, Albania) and obtained both biomass and $\mathrm{Ni}$ 
yields considerably higher than this study. This can be explained by the significantly lower soil $\mathrm{Ni}$ availability in the quarry experimental site compared to the Albanian ultramafic soils. Moreover, the results given by these authors were obtained after five years of optimising the cropping patterns and fertilisation regimes. Given that the results presented here are based on one single growth season, the efficiency of the system is expected to be progressively improved in subsequent growth cycles. The sub-optimal shoot $\mathrm{K}$ concentrations found in some plots and the elevated $\mathrm{Cu}$ and $\mathrm{Zn}$ concentrations in the compost may also have impaired plant growth and $\mathrm{Ni}$ accumulation of the study species. The severe drought conditions experienced affected plant survival, and the implementation of an irrigation system at the site is expected to help overcome this problem. Considering a plant survival rate of $100 \%$, the potential biomass yields for $B$. emarginata, $N$. caerulescens, $O$. muralis and O. serpyllifolia would be 293, 116, 295 and $291 \mathrm{~kg} \mathrm{ha}^{-1}$, respectively, in NPK plots, and 1951, 385, 5016 and $1069 \mathrm{~kg} \mathrm{ha}^{-1}$, respectively, in the CSS plots. The corresponding potential Ni yields would be 2.5, 2.0, 0.6 and $2.2 \mathrm{~kg} \mathrm{ha}^{-1}$, and 3.7, 3.1, 8.3 and $3.2 \mathrm{~kg} \mathrm{ha}^{-1}$, in the NPK and CSS plots, respectively. Further improvements in biomass and $\mathrm{Ni}$ yields are required if the process is to be economically viable, such as that reported by Bani et al. (2015a). Improvements could be achieved through agronomic practices, such as plant cropping patterns (intercropping with legumes) or increasing plant densities. For example, in the case of $B$. emarginata which showed a high survival rate, a plant density of 4 plants per $\mathrm{m}^{2}$ did not completely cover the soil surface and higher Ni yields may be obtained by optimising planting densities for this species. In the case of $N$. caerulescens, a higher planting density (81 plants $/ \mathrm{m}^{2}$ ) was used due to its small size; however, this density successfully covered the full surface area (in those plots where survival was high). Jacobs et al. (2018) found that the biomass production of $N$. caerulescens at a density of 100 plants $\mathrm{m}^{2}$ was highest but not double that obtained with 50 plants $\mathrm{m}^{2}$, indicating competition for resources, such as nutrients, water or light. However, no competition for metals was observed and plants showed similar shoot metal concentrations between the different planting densities. The authors suggested that the plants were forced to explore a wider volume of soil when grown at a high density. Planting density exerts a strong effect on plant growth and yield, and shoot metal concentration (Bani et al., 2015b; Li et al., 2003), and therefore needs to be assessed for each plant species and experimental site. In the case of $N$. caerulescens, the high number of plants required per unit surface area and its low biomass production make this plant species less appropriate for phytomining application.

\section{Conclusions}

To the best of our knowledge this is the first field study carried out which assesses Ni phytomining viability in serpentine mine-soils in the Iberian Peninsula. Clearly, plant species selection and further development of the technique is necessary to fully optimise plant survival, biomass production and Ni yields. Overall, the Mediterranean hyperaccumulators $B$. emarginata and $O$. muralis showed an extraordinary capacity to adapt to the unfavourable conditions of the mine-soil under the humid-temperate climate. On the other hand, the native hyperaccumulator $O$. serpyllifolia showed the lowest rates of survival in both NPK- and CSS-amended plots. Compost addition was more effective than NPK fertilisation and, together with plant growth, led to significant improvements in soil quality in terms of physico-chemical and biological properties. Amending with compost increased the total amount of Ni phytoextracted (the Ni yield), and this was mainly driven by the stimulation in biomass production rather than an increase in $\mathrm{Ni}$ uptake by the hyperaccumulating plants. The dilution effect observed regarding shoot $\mathrm{Ni}$ accumulation in the presence of compost, as well as the presence of potentially phytotoxic metals in this amendment, could limit both plant growth and Ni phytoextracted. Further studies should focus on the appropriate selection of the type of the organic amendment used, as well as the optimal addition rate, for increasing soil $\mathrm{Ni}$ availability and enhancing its uptake by hyperaccumulating plants while maximising plant biomass production. Overall, the results confirm the potential for phytomining to be part of a rehabilitation strategy during mining operations and after the closure of the mine.

\section{Acknowledgements}

The authors thank the financial support received by the Spanish Ministerio de Economía, Industria y Competitividad (Mineco) and the Fondo Europeo de Desarrollo Regional (FEDER) (CTM2015-66439-R), as well as the LIFE Environment and Resource Efficiency Programme (Life-Agromine; LIFE15 ENV/FR/000512).

\section{References}

Adam, G., Duncan, H., 2001. Development of a sensitive and rapid method for the measurement of total microbial activity using fluorescein diacetate (FDA) in a range of soils. Soil Biol. Biochem. 33, 943-951.

Álvarez-López, V., Prieto-Fernández, Á., Becerra-Castro, C., Monterroso, C., Kidd, P.S., 2016a. Rhizobacterial communities associated with the flora of three serpentine outcrops of the Iberian Peninsula. Plant Soil 403, 233-252. https://doi.org/10.1007/ s11104-015-2632-0.

Álvarez-López, V., Prieto-Fernández, Á., Cabello-Conejo, M.I., Kidd, P.S., 2016b. Organic amendments for improving biomass production and metal yield of Ni-hyperaccumulating plants. Sci. Total Environ. 548-549, 370-379. https://doi.org/10. 1016/j.scitotenv.2015.12.147.

Bani, A., Echevarria, G., Sulçe, S., Morel, J.L., Mullai, A., 2007. In-situ phytoextraction of Ni by a native population of Alyssum murale on an ultramafic site (Albania). Plant Soil 293, 79-89. https://doi.org/10.1007/s11104-007-9245-1.

Bani, A., Pavlova, D., Echevarria, G., Mullaj, A., Reeves, R.D., Morel, J.L., Sulçe, S., 2010. Nickel hyperaccumulation by the species of Alyssum and Thlaspi (Brassicaceae) from the ultramafic soils of the Balkans. Bot. Serbica 34, 3-14.

Bani, A., Echevarria, G., Sulçe, S., Morel, J.L., 2015a. Improving the agronomy of alyssum murale for extensive phytomining: a five-year field study. Int. J. Phytoremediation 17, 117-127. https://doi.org/10.1080/15226514.2013.862204.

Bani, A., Echevarria, G., Zhang, X., Benizri, E., Laubie, B., Morel, J.L., Simonnot, M.O., 2015b. The effect of plant density in nickel-phytomining field experiments with Alyssum murale in Albania. Aust. J. Bot. 63, 72-77. https://doi.org/10.1071/ BT14285.

Barbaroux, R., Plasari, E., Mercier, G., Simonnot, M.O., Morel, J.L., Blais, J.F., 2012. A new process for nickel ammonium disulfate production from ash of the hyperaccumulating plant Alyssum murale. Sci. Total Environ. 423, 111-119. https://doi. org/10.1016/j.scitotenv.2012.01.063.

Benbi, D.K., Thind, H.S., Sharma, S., Brar, K., Toor, A.S., 2017. Bagasse ash application stimulates agricultural soil $\mathrm{C}$ sequestration without inhibiting soil enzyme activity. Commun. Soil Sci. Plant Anal. 48, 1822-1833. https://doi.org/10.1080/00103624. 2017.1395455.

Burges, A., Epelde, L., Benito, G., Artetxe, U., Becerril, J.M., Garbisu, C., 2016. Enhancement of ecosystem services during endophyte-assisted aided phytostabilization of metal contaminated mine soil. Sci. Total Environ. 562, 480-492. https://doi. org /10.1016/j.scitotenv.2016.04.080.

Chardot, V., Massoura, S.T., Echevarria, G., Reeves, R.D., Morel, J.L., 2005. Phytoextraction potential of the nickel hyperaccumulators Leptoplax emarginata and Bornmuellera tymphaea. Int. J. Phytoremediation 7, 323-335. https://doi.org/10. $1080 / 16226510500327186$.

Chardot-Jacques, V., Calvaruso, C., Simon, B., Turpault, M.-P., Echevarria, G., Morel, J.L., 2013. Chrysotile dissolution in the rhizosphere of the nickel hyperaccumulator Leptoplax emarginata. Environ. Sci. Technol. 47, 2612-2620. https://doi.org/10. 1021/es301229m.

Dalvi, A.D., Bacon, W.G., Osborne, R.C., 2004. The past and the future of nickel laterites. PDAC 2004. Int. Conv. 1-27.

Dodson, J.R., Hunt, A.J., Parker, H.L., Yang, Y., Clark, J.H., 2012. Elemental sustainability: towards the total recovery of scarce metals. Chem. Eng. Process. Process Intensif. 51, 69-78. https://doi.org/10.1016/j.cep.2011.09.008.

EC, 2017. Study on the review of the list of critical raw materials - critical raw materials factsheets. European Commission. https://doi.org/10.2873/876644.

EC, 2018. EU-Report on Critical Raw Materials and the Circular Economy. https://ec. europa.eu/commission/publications/report-critical-raw-materials-and-circular economy es (Accessed $27^{\text {th }}$ Apr 2018).

Echevarria, G., 2018. Genesis and Behaviour of Ultramafic Soils and Consequences for Nickel Biogeochemistry. In: der Ent, A., Echevarria, G., Baker, A.J.M., Morel, J.L. (Eds.), Agromining: Farming for Metals: Extracting Unconventional Resources Using Plants. Springer International Publishing, Cham, pp. 135-156. https://doi.org/10 1007/978-3-319-61899-9_8.

Epelde, L., Becerril, J.M., Kowalchuk, G.A., Deng, Y., Zhou, J., Garbisu, C., 2010. Impact of metal pollution and Thlaspi caerulescens growth on soil microbial communities. Appl. Environ. Microbiol. 76, 7843-7853. https://doi.org/10.1128/AEM.01045-10.

Ernst, W.H.O., 2005. Phytoextraction of mine wastes - Options and impossibilities. Chem. Erde 65, 29-42. https://doi.org/10.1016/j.chemer.2005.06.001.

Garaiyurrebaso, O., Garbisu, C., Blanco, F., Lanzén, A., Martín, I., Epelde, L., Becerril, J.M., Jechalke, S., Smalla, K., Grohmann, E., Alkorta, I., 2017. Long-term effects of 
aided phytostabilisation on microbial communities of metal-contaminated mine soil. FEMS Microbiol. Ecol. 93, 1-14. https://doi.org/10.1093/femsec/fiw252.

Ghasemi, Z., Ghaderian, S.M., Monterroso, C., Kidd, P.S., 2018a. Improving the growth of Ni-hyperaccumulating plants in serpentine quarry tailings Improving the growth of Ni-hyperaccumulating plants in serpentine quarry tailings. Int. J. Phytoremediation 0, 1-10. https://doi.org/10.1080/15226514.2017.1413335.

Ghasemi, Z., Ghaderian, S.M., Rodríguez-Garrido, B., Prieto-Fernández, Á., Kidd, P.S., 2018b. Plant species-specificity and effects of bioinoculants and fertilization on plant performance for nickel phytomining. Plant Soil 1-21. https://doi.org/10.1007/ s11104-017-3553-x.

Harantová, L., Mudrák, O., Kohout, P., Elhottová, D., Frouz, J., Baldrian, P., 2017. Development of microbial community during primary succession in areas degraded by mining activities. L. Degrad. Dev. 28, 2574-2584. https://doi.org/10.1002/ldr. 2817.

IUSS Working Group WRB, 2014. World Reference Base for Soil Resources 2014. International Soil Classification System for Naming Soils and Creating Legends for Soil Maps, World Soil Resources Reports No. 106. https://doi.org/10.1017/ S0014479706394902.

Jacobs, A., De Brabandere, L., Drouet, T., Sterckeman, T., Noret, N., 2018. Phytoextraction of $\mathrm{Cd}$ and $\mathrm{Zn}$ with Noccaea caerulescens for urban soil remediation: influence of nitrogen fertilization and planting density. Ecol. Eng. 116, 178-187. https://doi.org/10.1016/j.ecoleng.2018.03.007.

Kabata-Pendias, A., Pendias, H., 2001. Trace elements in soils and plants. N. Y. https:// doi.org/10.1201/b10158-25.

Kidd, P., Barceló, J., Bernal, M.P., Navari-Izzo, F., Poschenrieder, C., Shilev, S., Clemente, R., Monterroso, C., 2009. Trace element behaviour at the root-soil interface: Implications in phytoremediation. Environ. Exp. Bot. 67, 243-259. https://doi.org/ 10.1016/j.envexpbot.2009.06.013.

Kidd, P.S., Álvarez-López, V., Becerra-Castro, C., Cabello-Conejo, M., Prieto-Fernández, Á., 2017. Potential role of plant-associated bacteria in plant metal uptake and implications in phytotechnologies. Adv. Bot. Res. 83, 87-126. https://doi.org/10.1016/ bs.abr.2016.12.004.

Lago-Vila, M., Rodríguez-Seijo, A., Arenas-Lago, D., Andrade, L., Vega, M.F.A., 2017. Heavy metal content and toxicity of mine and quarry soils. J. Soils Sediments 17 1331-1348. https://doi.org/10.1007/s11368-016-1354-0.

Li, Y.M., Chaney, R., Brewer, E., Roseberg, R., Angle, J.S., Baker, A., Reeves, R., Nelkin, J., 2003. Development of a technology for commercial phytoextraction of nickel: Economic and technical considerations. Plant Soil 249, 107-115. https://doi.org/10. 1023/A:1022527330401.

Lindsay, W.L., Norvell, W.A., 1978. Development of DTPA soil test for zinc, iron, manganese, and copper. Soil Sci. Soc. Am. J. 42, 421-428.

Losfeld, G., Mathieu, R., L'Huillier, L., Fogliani, B., Jaffré, T., Grison, C., 2015. Phytoextraction from mine spoils: insights from New Caledonia. Environ. Sci. Pollut. Res. 22, 5608-5619. https://doi.org/10.1007/s11356-014-3866-8.

Lützow, M.V., Kögel-Knabner, I., Ekschmitt, K., Matzner, E., Guggenberger, G. Marschner, B., Flessa, H., 2006. Stabilization of organic matter in temperate soils: mechanisms and their relevance under different soil conditions - a review. Eur. J. Soil Sci. 57, 426-445. https://doi.org/10.1111/j.1365-2389.2006.00809.x.

Macías, F.V., Calvo, R.A., Pena-Pérez, X., 2009. Niveles genéricos de referencia de metales pesados y otros elementos traza en suelos de Galicia. In: Consellería de Medio Ambiente e Desenvolvemento Sostible. Xunta de Galicia, Santiago de Compostela, Spain.

Mengoni, A., Schat, H., Vangronsveld, J., 2010. Plants as extreme environments? Ni-resistant bacteria and Ni-hyperaccumulators of serpentine flora. Plant Soil 331, 5-16. https://doi.org/10.1007/s11104-009-0242-4.

Nkrumah, P.N., Baker, A.J.M., Chaney, R.L., Erskine, P.D., Echevarria, G., Morel, J.L., van der Ent, A., 2016. Current status and challenges in developing nickel phytomining: an agronomic perspective. Plant Soil 406, 55-69. https://doi.org/10.1007/s11104-0162859-4.

Pardo, T., Clemente, R., Epelde, L., Garbisu, C., Bernal, M.P., 2014. Evaluation of the phytostabilisation efficiency in a trace elements contaminated soil using soil health indicators. J. Hazard. Mater. 268, 68-76. https://doi.org/10.1016/j.jhazmat.2014. 01.003.

Pardo, T., Rodríguez-Garrido, B., Saad, R.F., Soto-Vázquez, J.L., Loureiro-Viñas, M., Prieto-Fernández, Á., Echevarria, G., Benizri, E., Kidd, P.S., 2018. Assessing the agromining potential of Mediterranean nickel-hyperaccumulating plant species at field-scale in ultramafic soils under humid-temperate climate. Sci. Total Environ. 630, 275-286. https://doi.org/10.1016/j.scitotenv.2018.02.229.

Pollard, A.J., Reeves, R.D., Baker, A.J.M., 2014. Facultative hyperaccumulation of heavy metals and metalloids. Plant Sci. 217-218, 8-17. https://doi.org/10.1016/j.plantsci. 2013.11.011.

Proctor, J., Woodell, S.R.J., 1975. The ecology of serpentine soils. Adv. Ecol. Res. 9, 255-366. https://doi.org/10.1016/S0065-2504(08)60291-3.

Puschenreiter, M., Schnepf, A., Millán, I.M., Fitz, W.J., Horak, O., Klepp, J., Schrefl, T., Lombi, E., Wenzel, W.W., 2005. Changes of Ni biogeochemistry in the rhizosphere of the hyperaccumulator Thlaspi goesingense. Plant Soil 271, 205-218. https://doi.org/ 10.1007/s11104-004-2387-5.

Reeves, R.D., Schwartz, C., Morel, J.L., Edmondson, J., 2001. Distribution and metalaccumulating behavior of Thlaspi caerulescens and associated metallophytes in France. Int. J. Phytoremediation 3, 145-172. https://doi.org/10.1080/15226510108500054.

Reeves, R.D., van der Ent, A., Baker, A.J.M., 2018. Global distribution and ecology of hyperaccumulator plants. In: van der Ent, A., Echevarria, G., Baker, A.J.M., Morel, J.L. (Eds.), Agromining: Farming for Metals: Extracting Unconventional Resources Using Plants. Springer International Publishing, Cham, pp. 75-92. https://doi.org/ 10.1007/978-3-319-61899-9.

Rešetnik, I., Satovic, Z., Schneeweiss, G.M., Liber, Z., 2013. Phylogenetic relationships in Brassicaceae tribe Alysseae inferred from nuclear ribosomal and chloroplast DNA sequence data. Mol. Phylogenet. Evol. 69, 772-786. https://doi.org/10.1016/j. ympev.2013.06.026.

Rodríguez-Seijo, A., Arenas-Lago, D., Lago-Vila, M., Vega, F.A., Andrade Couce, L., 2014 Limitations for revegetation in lead/zinc minesoils (NW Spain). J. Soils Sediments 14, 785-793. https://doi.org/10.1007/s11368-013-0826-8.

Schlegel, H.G., Kaltwasser, H., Gottschalk, G., 1961. Ein Sumbersverfahren zur Kultur wasserstoffoxidierender Bakterien: wachstum physiologische Untersuchingen. Arch. Mikrobiol. 38, 209-222.

Sheoran, V., Sheoran, A.S., Poonia, P., 2009. Phytomining: a review. Miner. Eng. 22, 1007-1019. https://doi.org/10.1016/j.mineng.2009.04.001.

Simonnot, M.-O., Vaughan, J., Laubie, B., 2018. Processing of Bio-Ore to Products. Springer International Publishing, pp. 39-51. https://doi.org/10.1007/978-3-31961899-9 3

van der Ent, A., Baker, A.J.M., van Balgooy, M.M.J., Tjoa, A., 2013. Ultramafic nickel laterites in Indonesia (Sulawesi, Halmahera): mining, nickel hyperaccumulators and opportunities for phytomining. J. Geochemical Explor. 128, 72-79. https://doi.org/ 10.1016/j.gexplo.2013.01.009.

van der Ent, A., Baker, A.J.M., Reeves, R.D., Chaney, R.L., Anderson, C.W.N., Meech, J.A., Erskine, P.D., Simonnot, M.-O., Vaughan, J., Morel, J.L., Echevarria, G., Fogliani, B., Rongliang, Q., Mulligan, D.R., 2015. Agromining: farming for metals in the future? Environ. Sci. Technol. 49, 4773-4780.

Wenzel, W.W., Bunkowski, M., Puschenreiter, M., Horak, O., 2003. Rhizosphere characteristics of indigenously growing nickel hyperaccumulator and excluder plants on serpentine soil. Environ. Pollut. 123, 131-138. https://doi.org/10.1016/S02697491(02)00341-X. 